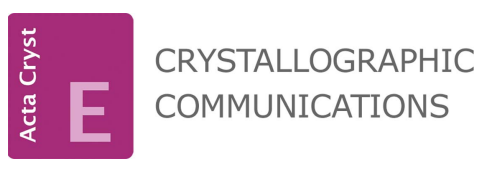

ISSN 2056-9890

\section{Crystal structures of two mononuclear complexes of terbium(III) nitrate with the tripodal alcohol 1,1,1-tris(hydroxymethyl)propane}

\author{
Thaiane Gregório, ${ }^{\text {a }}$ Siddhartha O. K. Giese, ${ }^{a}$ Giovana G. Nunes, ${ }^{a}$ Jaísa F. Soares ${ }^{\mathrm{a} *}$ \\ and David L. Hughes ${ }^{b}$ *
}

Received 17 January 2017

Accepted 23 January 2017

Edited by W. T. A. Harrison, University of

Keywords: crystal structure; lanthanide; terbium(III); nitrate; mononuclear; tripodal alcohol.

CCDC references: 1529079; 1529078

Supporting information: this article has supporting information at journals.iucr.org/e Aberdeen, Scotland

Departamento de Química, Universidade Federal do Paraná, Centro Politécnico, Jardim das Américas, 81530-900
Curitiba-PR, Brazil, and 'bSchool of Chemistry, University of East Anglia, University Plain, Norwich NR4 7TJ, UK.
${ }^{*}$ Correspondence e-mail: jaisa@quimica.ufpr.br, d.I.hughes@uea.ac.uk

Two new mononuclear cationic complexes in which the $\mathrm{Tb}^{\mathrm{III}}$ ion is bis-chelated by the tripodal alcohol 1,1,1-tris(hydroxymethyl)propane $\left(\mathrm{H}_{3} L^{\mathrm{Et}}, \mathrm{C}_{6} \mathrm{H}_{14} \mathrm{O}_{3}\right)$ were prepared from $\mathrm{Tb}\left(\mathrm{NO}_{3}\right)_{3} \cdot 5 \mathrm{H}_{2} \mathrm{O}$ and had their crystal and molecular structures solved by single-crystal $\mathrm{X}$-ray diffraction analysis after data collection at $100 \mathrm{~K}$. Both products were isolated in reasonable yields from the same reaction mixture by using different crystallization conditions. The highersymmetry complex dinitratobis[1,1,1-tris(hydroxymethyl)propane]terbium(III) nitrate dimethoxyethane hemisolvate, $\left[\mathrm{Tb}\left(\mathrm{NO}_{3}\right)_{2}\left(\mathrm{H}_{3} L^{\mathrm{Et}}\right)_{2}\right] \mathrm{NO}_{3} \cdot 0.5 \mathrm{C}_{4} \mathrm{H}_{10} \mathrm{O}_{2}, \mathbf{1}$, in which the lanthanide ion is 10-coordinate and adopts an $s$-bicapped squareantiprismatic coordination geometry, contains two bidentate nitrate ions bound to the metal atom; another nitrate ion functions as a counter-ion and a halfmolecule of dimethoxyethane (completed by a crystallographic twofold rotation axis) is also present. In product aquanitratobis[1,1,1-tris(hydroxymethyl)propane]terbium(III) dinitrate, $\left[\mathrm{Tb}\left(\mathrm{NO}_{3}\right)\left(\mathrm{H}_{3} L^{\mathrm{Et}}\right)_{2}\left(\mathrm{H}_{2} \mathrm{O}\right)\right]\left(\mathrm{NO}_{3}\right)_{2}$, 2, one bidentate nitrate ion and one water molecule are bound to the nine-coordinate terbium(III) centre, while two free nitrate ions contribute to charge balance outside the tricapped trigonal-prismatic coordination polyhedron. No free water molecule was found in either of the crystal structures and, only in the case of $\mathbf{1}$, dimethoxyethane acts as a crystallizing solvent. In both molecular structures, the two tripodal ligands are bent to one side of the coordination sphere, leaving room for the anionic and water ligands. In complex $\mathbf{2}$, the methyl group of one of the $\mathrm{H}_{3} L^{\mathrm{Et}}$ ligands is disordered over two alternative orientations. Strong hydrogen bonds, both intra- and intermolecular, are found in the crystal structures due to the number of different donor and acceptor groups present.

\section{Chemical context}

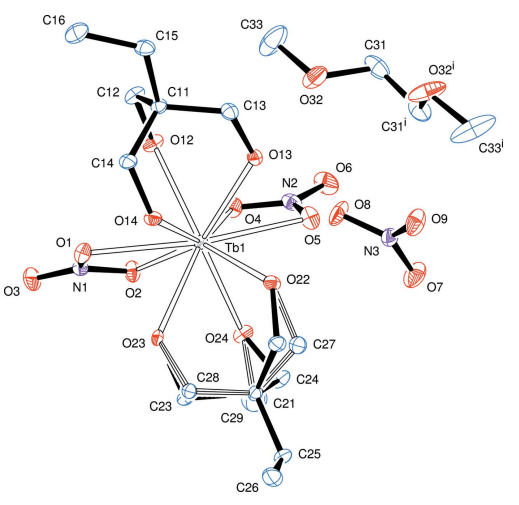

Our interest in developing synthetic routes for the synthesis of mono- or polynuclear complexes containing lanthanide(III) ions is based on the possibility that these compounds behave as single-ion (SIM) or single-molecule (SMM) magnets (Benelli \& Gatteschi, 2015; Gatteschi et al., 2006; Frost et al., 2016; Meng et al., 2016). In such chemical species, it is usually possible to exploit the strong spin-orbit coupling, the relatively high-spin angular momentum and the large magnetic anisotropy presented by lanthanides to maximize the energy barrier for the reversal of the magnetization (Luzon \& Sessoli, 2012; Vieru et al., 2016; Sessoli \& Powell, 2009) and therefore increase the technological applicability of these materials.

With this objective in mind, our first steps were the synthesis and characterization of complexes containing $L n^{\mathrm{III}}$ ions that 
could be used as building blocks for polynuclear $3 d-4 f$ block metal aggregates. The first report of a heterometallic complex of this type that showed SMM behaviour described the tetranuclear molecule $\left[\left\{\mathrm{Cu}^{\mathrm{II}} L \mathrm{~Tb}^{\mathrm{III}}(\mathrm{Hfac})_{2}\right\}_{2}\right]\left[\mathrm{H}_{3} L=1-(2-\right.$ hydroxybenzamido)-2-(2-hydroxy-3-methoxy-benzylidene amino)ethane and $\mathrm{Hfac}=$ hexafluoroacetylacetone], obtained by self-assembly (Osa et al., 2004). Magnetic studies of the product revealed ferromagnetic exchange and slow relaxation of the magnetization at low temperatures, with a potential energy barrier $\Delta / k B$ of $21 \mathrm{~K}\left(14.7 \mathrm{~cm}^{-1}\right)$.

After this report, many other heterometallic complexes containing $3 d$ and $4 f$ ions with different structures and nuclearities were characterized as single-molecule magnets (Liu et al., 2015). In 2014, a trinuclear complex of dysprosium(III) and iron(II) presented the largest potential energy barrier reported to date for this type of system. The molecule, formulated as $\left[\mathrm{Fe}^{\mathrm{II}}{ }_{2} \mathrm{Dy}{ }^{\mathrm{III}} L_{2}\left(\mathrm{H}_{2} \mathrm{O}\right)\right] \mathrm{ClO}_{4} \cdot 2 \mathrm{H}_{2} \mathrm{O}, L=2,2^{\prime}, 2^{\prime \prime}$ \{[nitrilotris(ethane-2,1-diyl)]tris(azanediyl)methylene\}tris(4chlorophenol), and also synthesized in a self-assembly reaction, presents two iron(II) ions in different coordination environments (octahedral and distorted trigonal prismatic) bound to a dysprosium(III) ion in quasi- $D_{5 h}$ symmetry, which is pointed out by the authors as fundamental for the observed SMM behaviour and for the impressive potential energy barrier of $459 \mathrm{~K}\left(319 \mathrm{~cm}^{-1}\right)$ (Liu et al., 2014). This value, although lower than the record figures reported for lanthanide-containing SIM compounds (Liu et al., 2016), still reveals the potential of mixed $3 d-4 f$ metal complexes to behave as quantum magnets.

Despite these good results, most of the experimental procedures employed for the preparation of these polynuclear compounds involve self-assembly reactions, which often compete with the rational design of the desired molecules. Many efforts have been directed recently to the development of synthetic routes that allow for greater predictability of the formed products, both structural and with respect to their magnetic properties, employing simple and elegant experimental procedures that include modular synthesis approaches (Kahn, 1997; Stumpf et al., 1993).

In this context, the present work involved reactions between the tripodal alcohol $\mathrm{H}_{3} L^{\mathrm{Et}}$ [1,1,1-tris(hydroxymethyl)propane] and $\mathrm{Tb}\left(\mathrm{NO}_{3}\right)_{3} \cdot 5 \mathrm{H}_{2} \mathrm{O}$ that generated the new, cationic complexes $\left[\mathrm{Tb}\left(\mathrm{H}_{3} L^{\mathrm{Et}}\right)_{2}\left(\mathrm{NO}_{3}\right)_{2}\right]\left(\mathrm{NO}_{3}\right) \cdot 0.5$ glyme (product 1) and $\left[\mathrm{Tb}\left(\mathrm{H}_{3} L^{\mathrm{Et}}\right)_{2}\left(\mathrm{NO}_{3}\right)\left(\mathrm{H}_{2} \mathrm{O}\right)\right]\left(\mathrm{NO}_{3}\right)_{2}$ (product 2). In both cases, the coordination environment of the lanthanide ion is similar to that observed in the central unit (core) of starshaped heterometallic SMMs of general formula $\left[M_{3} M^{\prime}\left(L^{\mathrm{Et}}\right)_{2}(\mathrm{dpm})_{3}\right]\left(M\right.$ and $M^{\prime}=$ transition metal(III) ions; $L^{\mathrm{Et}}=\operatorname{EtC}\left(\mathrm{CH}_{2} \mathrm{O}\right)_{3}{ }^{3-}$ tripodal alkoxide and $\mathrm{Hdpm}=$ dipivaloylmethane) (Accorsi et al., 2006; Totaro et al., 2013; Westrup et al., 2014; Gregoli et al., 2009). Complexes 1 and 2 were characterized by elemental and X-ray diffraction analysis, together with vibrational (infrared) spectroscopy. These products are potential building blocks to be subsequently combined, in stoichiometric proportions, with other $3 d$ and $4 f$ starting materials to give heterometallic products with potentially interesting magnetic properties.

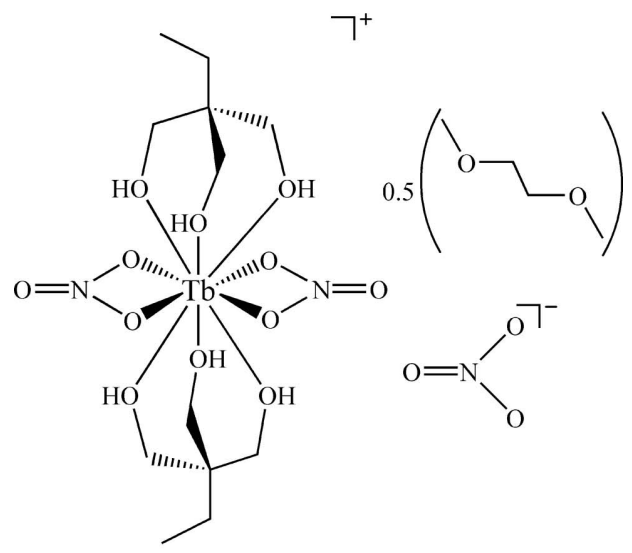

(1)

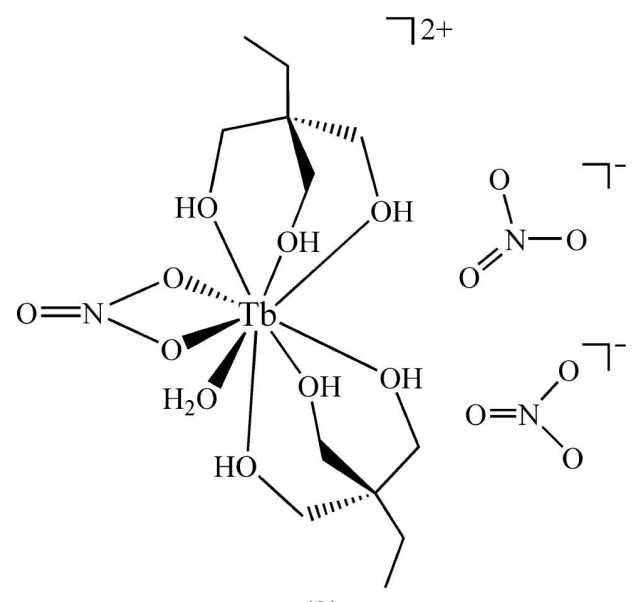

(2)

\section{Structural commentary}

The crystals of product 1 contain the mononuclear complex $\left[\mathrm{Tb}\left(\mathrm{H}_{3} L^{\mathrm{Et}}\right)_{2}\left(\mathrm{NO}_{3}\right)_{2}\right]\left(\mathrm{NO}_{3}\right) \cdot 0.5$ glyme (Fig. 1), in which the terbium(III) ion is 10 -coordinate, being connected to six hydroxyl groups of the tripodal alcohol molecules and to two bidentate nitrate ions. There is also one nitrate ion (acting as a counter-ion); a solvating dimethoxyethane (glyme) molecule is shared between two units of the cationic complex. The complete gylme molecule is completed by a crystallographic twofold rotation axis.

The geometric arrangement of the oxygen donor atoms about the metal atom in $\mathbf{1}$ is closer to a distorted $s$-bicapped square antiprism, Fig. 2, than to an $s$-bicapped dodecahedron (Rohrbaugh \& Jacobson, 1974). The choice of the bicapped square-antiprismatic coordination sphere is mainly based on the angles between the coordinating oxygen atoms presented in Table 1, which are closer to the expected $90^{\circ}$ values of the square planes in the former (Fig. 2) than to the alternating $c a$ 77 and $100^{\circ}$ angles in the latter (Rohrbaugh \& Jacobson, 1974).

The mean square planes represented in Fig. 2 form a dihedral angle of $5.58^{\circ}$ in the complex cation of $\mathbf{1}$. The capping atoms, $\mathrm{O} 1$ and $\mathrm{O} 5$, both belong to the bidentate $\mathrm{NO}_{3}{ }^{-}$ligands and form the two longest $\mathrm{Tb}-\mathrm{O}$ bonds in the structure of $\mathbf{1}$, 


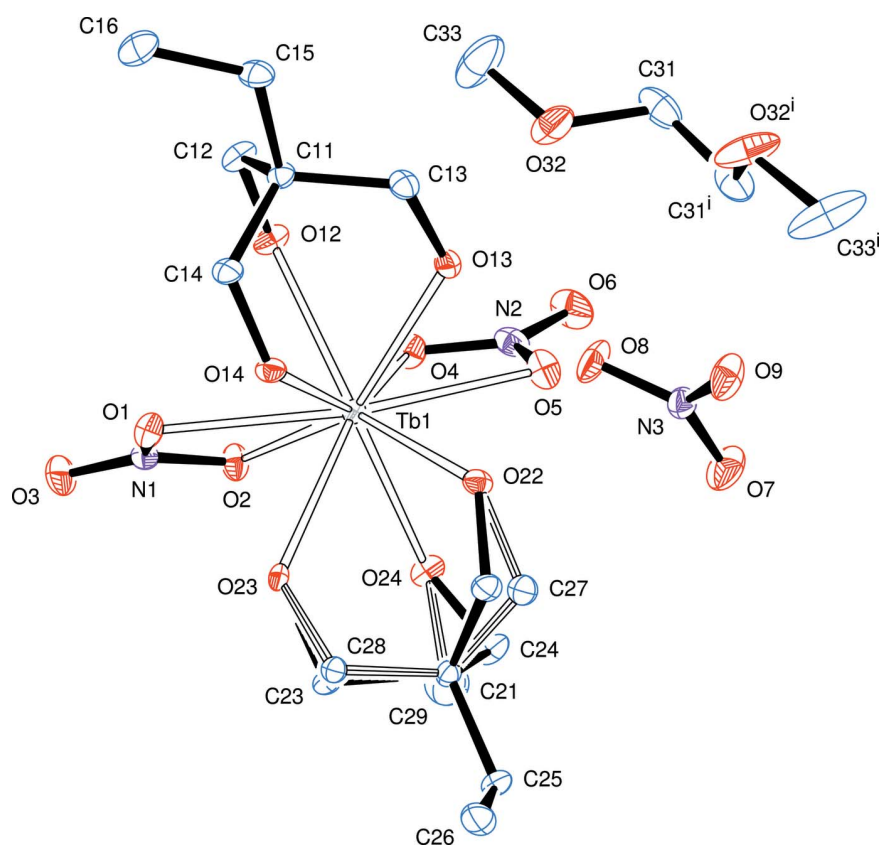

Figure 1

ORTEP representation of product $\mathbf{1}, \quad\left[\mathrm{Tb}\left(\mathrm{H}_{3} L^{\mathrm{Et}}\right)_{2}\left(\mathrm{NO}_{3}\right)_{2}\right]\left(\mathrm{NO}_{3}\right)$-$0.5 \mathrm{C}_{4} \mathrm{H}_{10} \mathrm{O}_{2}\left(\mathrm{H}_{3} L^{\mathrm{Et}}=1,1,1\right.$-tris(hydroxymethyl) propane and $\mathrm{C}_{4} \mathrm{H}_{10} \mathrm{O}_{2}=$ dimethoxyethane), with the atom-numbering scheme. There is disorder in the tripodal ligand of $\mathrm{C} 21$, with the minor component shown with striped bonds. Hydrogen atoms were omitted for clarity, and displacement ellipsoids are drawn at the $50 \%$ probability level. [Symmetry code: (i) $-x+\frac{1}{2}, y, 1-z$.]

2.5697 (13) and 2.5874 (14) , respectively. Because of the typically small bite angles of the chelating nitrate ions, $49.50(4)^{\circ}$ for $\mathrm{O} 2-\mathrm{Tb} 1-\mathrm{O} 1$ and $50.12(4)^{\circ}$ for $\mathrm{O} 4-\mathrm{Tb} 1-\mathrm{O} 5$, the $\mathrm{Tb}-\mathrm{O} 1$ and $\mathrm{Tb}-\mathrm{O} 5$ bonds are significantly bent towards $\mathrm{O} 2$ and $\mathrm{O} 4$, respectively, creating additional structural distortion.

The average $\mathrm{Tb}-\mathrm{O}$ bond involving the bidentate nitrate ligands in $\mathbf{1}$ [2.549 $\AA$, and Table 2] is shorter than that described by Delangle and co-workers for the lanthanum(III) cation $\left[\mathrm{La}\left(\mathrm{H}_{3} L^{1}\right)_{2}\left(\mathrm{NO}_{3}\right)_{2}\right]^{+}, \mathrm{H}_{3} L^{1}=$ cis,cis-1,3,5-trihydroxycyclohexane; average $=2.681 \AA$; ; Delangle et al., 2001]. This agrees with the smaller effective ionic radius of the $\mathrm{Tb}^{\mathrm{III}}$ ion as compared to that of $\mathrm{La}^{\mathrm{III}}$ (for example 1.095 versus $1.216 \AA$ for

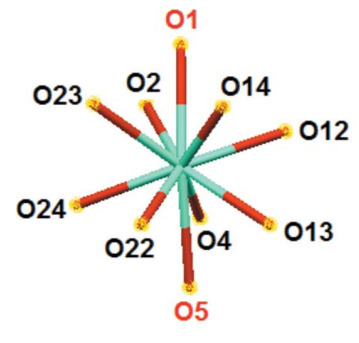

Figure 2

Plot of the coordination sphere (left) and schematic representation of the coordination environment about the terbium(III) atom in product $\mathbf{1}$. The two mutually rotated square faces $\mathrm{O} 2-\mathrm{O} 12-\mathrm{O} 14-\mathrm{O} 23$ and $\mathrm{O} 13-\mathrm{O} 22-$ $\mathrm{O} 24-\mathrm{O} 4$ are capped by atoms $\mathrm{O} 1$ and $\mathrm{O} 5$, respectively.
Table 1

Selected non-bonding angles $\left({ }^{\circ}\right)$ in the molecular structure of product $\mathbf{1}$.

\begin{tabular}{llll}
\hline $\mathrm{O} 24 \cdots \mathrm{O} 22 \cdots \mathrm{O} 13$ & 101.47 & $\mathrm{O} 2 \cdots \mathrm{O} 23 \cdots \mathrm{O} 14$ & 86.82 \\
$\mathrm{O} 22 \cdots \mathrm{O} 13 \cdots \mathrm{O} 4$ & 83.25 & $\mathrm{O} 23 \cdots \mathrm{O} 14 \cdots \mathrm{O} 12$ & 100.40 \\
$\mathrm{O} 13 \cdots \mathrm{O} 4 \cdots \mathrm{O} 24$ & 81.56 & $\mathrm{O} 14 \cdots \mathrm{O} 12 \cdots \mathrm{O} 2$ & 86.34 \\
$\mathrm{O} 4 \cdots \mathrm{O} 24 \cdots \mathrm{O} 22$ & 93.06 & $\mathrm{O} 12 \cdots \mathrm{O} 2 \cdots \mathrm{O} 23$ & 84.98 \\
\hline
\end{tabular}

nine-coordination respectively; Shannon, 1976). The effective ionic radius for 10-coordinate terbium(III) is not available in the literature. The mean $\mathrm{Tb}-\mathrm{O}$ bond to the tripodal $\mathrm{H}_{3} L^{\mathrm{Et}}$ ligands is $2.404 \AA$, again significantly shorter than in the lanthanum(III)-cyclic triol analogue mentioned above (average $=2.542 \AA$ ). The lack of other reported lanthanide complexes with a bis(tripodal alcohol)-bis(bidentate nitrate) coordination environment similar to that found in $\mathbf{1}$ restricts further comparisons.

The slow mixing of a hexane layer into the same reaction mixture that gave product $\mathbf{1}$ afforded another set of colourless crystals, product 2, in high yield (see Synthesis and crystallization). As for $\mathbf{1}$, crystals of $\mathbf{2}$ were practically insoluble at room temperature in hexane, toluene, thf, glyme and acetonitrile, but soluble in the last three solvents after heating at $c a$ $323 \mathrm{~K}$.

Single-crystal X-ray diffraction analysis of $\mathbf{2}$ revealed again a mononuclear complex, this time of formula $\left[\mathrm{Tb}\left(\mathrm{H}_{3} L^{\mathrm{Et}}\right)_{2^{-}}\right.$ $\left.\left(\mathrm{NO}_{3}\right)\left(\mathrm{H}_{2} \mathrm{O}\right)\right]\left(\mathrm{NO}_{3}\right)_{2}$ (Fig. 3), in which the coordination number of the metal atom is nine. In this case, the terbium(III) atom is coordinated by six hydroxyl groups of the tripodal alcohols, a bidentate nitrate ion and one water molecule probably coming from the $\mathrm{Tb}\left(\mathrm{NO}_{3}\right)_{3} \cdot 5 \mathrm{H}_{2} \mathrm{O}$ starting material. Two distinct non-coordinating nitrate anions complete the charge balance in the product.

The geometry adopted by the metal atom in $\mathbf{2}$ is close to a tri-capped trigonal prism, as reported for complexes $\left[L n\left(\mathrm{H}_{3} L^{1}\right)_{2}\left(\mathrm{NO}_{3}\right)\left(\mathrm{H}_{2} \mathrm{O}\right)\right]\left(\mathrm{NO}_{3}\right)_{2}\left(L n=\mathrm{Ho}^{\mathrm{III}}, \mathrm{Eu}^{\mathrm{III}}\right.$ and $\mathrm{Yb}^{\mathrm{III}}$; $\mathrm{H}_{3} L^{1}=$ cis,cis-1,3,5-trihydroxycyclohexane; Husson et al.,

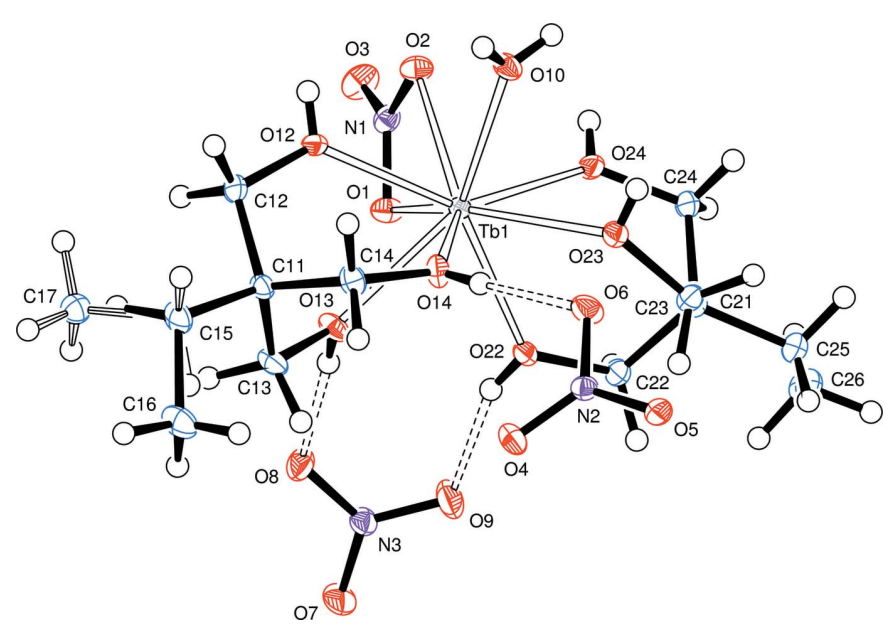

Figure 3

ORTEP representation of product $2,\left[\mathrm{~Tb}\left(\mathrm{H}_{3} L^{\mathrm{Et}}\right)_{2}\left(\mathrm{NO}_{3}\right)\left(\mathrm{H}_{2} \mathrm{O}\right)\right]\left(\mathrm{NO}_{3}\right)_{2}$, with the atom-numbering scheme. The terminal methyl group on $\mathrm{C} 15$ is disordered; the bonding of the minor component is shown with a striped bond. Displacement ellipsoids correspond to the $50 \%$ probability level. Hydrogen bonds are indicated by double-dashed lines. 
Table 2

Metal-oxygen distances ( $\mathrm{A})$ in the two complexes, $\mathbf{1}$ and $\mathbf{2}$

\begin{tabular}{|c|c|c|c|}
\hline \multicolumn{2}{|l|}{ Complex 1} & \multicolumn{2}{|l|}{ Complex 2} \\
\hline $\mathrm{Tb} 1-\mathrm{O} 1$ & $2.5697(13)$ & $\mathrm{Tb} 1-\mathrm{O} 1$ & $2.4706(10)$ \\
\hline $\mathrm{Tb} 1-\mathrm{O} 2$ & $2.5418(13)$ & $\mathrm{Tb} 1-\mathrm{O} 2$ & $2.4762(9)$ \\
\hline $\mathrm{Tb} 1-\mathrm{O} 4$ & 2.4953 (13) & $\mathrm{Tb} 1-\mathrm{O} 10$ & $2.3786(9)$ \\
\hline $\mathrm{Tb} 1-\mathrm{O} 5$ & $2.5874(14)$ & & \\
\hline $\mathrm{Tb} 1-\mathrm{O} 12$ & $2.4078(13)$ & $\mathrm{Tb} 1-\mathrm{O} 12$ & $2.3597(9)$ \\
\hline $\mathrm{Tb} 1-\mathrm{O} 13$ & $2.4245(14)$ & $\mathrm{Tb} 1-\mathrm{O} 13$ & $2.4119(9)$ \\
\hline $\mathrm{Tb} 1-\mathrm{O} 14$ & $2.3810(14)$ & $\mathrm{Tb} 1-\mathrm{O} 14$ & $2.3545(9)$ \\
\hline $\mathrm{Tb} 1-\mathrm{O} 22$ & $2.3583(13)$ & $\mathrm{Tb} 1-\mathrm{O} 22$ & $2.3734(9)$ \\
\hline $\mathrm{Tb} 1-\mathrm{O} 23$ & 2.4749 (14) & $\mathrm{Tb} 1-\mathrm{O} 23$ & $2.4344(9)$ \\
\hline $\mathrm{Tb} 1-\mathrm{O} 24$ & $2.3790(13)$ & $\mathrm{Tb} 1-\mathrm{O} 24$ & $2.4112(9)$ \\
\hline $\mathrm{O} 12-\mathrm{Tb} 1-\mathrm{O} 13$ & $66.85(5)$ & $\mathrm{O} 12-\mathrm{Tb} 1-\mathrm{O} 13$ & $68.99(3)$ \\
\hline $\mathrm{O} 14-\mathrm{Tb} 1-\mathrm{O} 12$ & $76.53(5)$ & $\mathrm{O} 14-\mathrm{Tb} 1-\mathrm{O} 12$ & $72.38(3)$ \\
\hline $\mathrm{O} 22-\mathrm{Tb} 1-\mathrm{O} 12$ & $136.11(5)$ & $\mathrm{O} 12-\mathrm{Tb} 1-\mathrm{O} 22$ & $140.67(3)$ \\
\hline $\mathrm{O} 12-\mathrm{Tb} 1-\mathrm{O} 23$ & $130.08(5)$ & $\mathrm{O} 12-\mathrm{Tb} 1-\mathrm{O} 23$ & $131.17(3)$ \\
\hline $\mathrm{O} 24-\mathrm{Tb} 1-\mathrm{O} 12$ & $147.08(5)$ & $\mathrm{O} 12-\mathrm{Tb} 1-\mathrm{O} 24$ & $141.14(3)$ \\
\hline $\mathrm{O} 14-\mathrm{Tb} 1-\mathrm{O} 13$ & $70.11(5)$ & $\mathrm{O} 14-\mathrm{Tb} 1-\mathrm{O} 13$ & $70.72(3)$ \\
\hline $\mathrm{O} 22-\mathrm{Tb} 1-\mathrm{O} 13$ & $71.20(5)$ & $\mathrm{O} 22-\mathrm{Tb} 1-\mathrm{O} 13$ & $71.69(3)$ \\
\hline $\mathrm{O} 13-\mathrm{Tb} 1-\mathrm{O} 23$ & $129.41(5)$ & $\mathrm{O} 13-\mathrm{Tb} 1-\mathrm{O} 23$ & $123.37(3)$ \\
\hline $\mathrm{O} 24-\mathrm{Tb} 1-\mathrm{O} 13$ & $128.37(5)$ & $\mathrm{O} 24-\mathrm{Tb} 1-\mathrm{O} 13$ & $134.33(3)$ \\
\hline $\mathrm{O} 22-\mathrm{Tb} 1-\mathrm{O} 14$ & $77.75(5)$ & $\mathrm{O} 14-\mathrm{Tb} 1-\mathrm{O} 22$ & $93.64(3)$ \\
\hline $\mathrm{O} 14-\mathrm{Tb} 1-\mathrm{O} 23$ & $70.24(5)$ & $\mathrm{O} 14-\mathrm{Tb} 1-\mathrm{O} 23$ & $69.97(3)$ \\
\hline $\mathrm{O} 24-\mathrm{Tb} 1-\mathrm{O} 14$ & $133.94(5)$ & $\mathrm{O} 14-\mathrm{Tb} 1-\mathrm{O} 24$ & $138.28(3)$ \\
\hline $\mathrm{O} 22-\mathrm{Tb} 1-\mathrm{O} 23$ & $70.76(5)$ & $\mathrm{O} 22-\mathrm{Tb} 1-\mathrm{O} 23$ & $71.90(3)$ \\
\hline $\mathrm{O} 22-\mathrm{Tb} 1-\mathrm{O} 24$ & $72.47(5)$ & $\mathrm{O} 22-\mathrm{Tb} 1-\mathrm{O} 24$ & $72.06(3)$ \\
\hline $\mathrm{O} 24-\mathrm{Tb} 1-\mathrm{O} 23$ & $67.19(5)$ & $\mathrm{O} 24-\mathrm{Tb} 1-\mathrm{O} 23$ & $68.34(3)$ \\
\hline $\mathrm{O} 2-\mathrm{Tb} 1-\mathrm{O} 1$ & $49.50(4)$ & $\mathrm{O} 1-\mathrm{Tb} 1-\mathrm{O} 2$ & $51.89(3)$ \\
\hline $\mathrm{O} 4-\mathrm{Tb} 1-\mathrm{O} 1$ & $104.45(4)$ & $\mathrm{O} 10-\mathrm{Tb} 1-\mathrm{O} 1$ & $124.95(3)$ \\
\hline $\mathrm{O} 1-\mathrm{Tb} 1-\mathrm{O} 5$ & $154.57(4)$ & $\mathrm{O} 10-\mathrm{Tb} 1-\mathrm{O} 2$ & 73.09 (3) \\
\hline $\mathrm{O} 4-\mathrm{Tb} 1-\mathrm{O} 2$ & $62.06(4)$ & & \\
\hline $\mathrm{O} 2-\mathrm{Tb} 1-\mathrm{O} 5$ & $107.78(4)$ & & \\
\hline $\mathrm{O} 4-\mathrm{Tb} 1-\mathrm{O} 5$ & $50.12(4)$ & & \\
\hline $\mathrm{O} 12-\mathrm{Tb} 1-\mathrm{O} 1$ & $69.27(5)$ & $\mathrm{O} 12-\mathrm{Tb} 1-\mathrm{O} 1$ & $88.98(3)$ \\
\hline $\mathrm{O} 13-\mathrm{Tb} 1-\mathrm{O} 1$ & $125.17(4)$ & $\mathrm{O} 13-\mathrm{Tb} 1-\mathrm{O} 1$ & $71.02(3)$ \\
\hline $\mathrm{O} 14-\mathrm{Tb} 1-\mathrm{O} 1$ & $69.06(4)$ & $\mathrm{O} 14-\mathrm{Tb} 1-\mathrm{O} 1$ & $141.34(3)$ \\
\hline $\mathrm{O} 22-\mathrm{Tb} 1-\mathrm{O} 1$ & $130.92(4)$ & $\mathrm{O} 22-\mathrm{Tb} 1-\mathrm{O} 1$ & $79.51(3)$ \\
\hline $\mathrm{O} 23-\mathrm{Tb} 1-\mathrm{O} 1$ & $64.60(4)$ & $\mathrm{O} 23-\mathrm{Tb} 1-\mathrm{O} 1$ & $139.42(3)$ \\
\hline $\mathrm{O} 24-\mathrm{Tb} 1-\mathrm{O} 1$ & $106.31(4)$ & $\mathrm{O} 24-\mathrm{Tb} 1-\mathrm{O} 1$ & 75.88 (3) \\
\hline $\mathrm{O} 12-\mathrm{Tb} 1-\mathrm{O} 2$ & $80.97(5)$ & $\mathrm{O} 12-\mathrm{Tb} 1-\mathrm{O} 2$ & $73.16(3)$ \\
\hline $\mathrm{O} 13-\mathrm{Tb} 1-\mathrm{O} 2$ & $144.10(5)$ & $\mathrm{O} 13-\mathrm{Tb} 1-\mathrm{O} 2$ & $110.27(3)$ \\
\hline $\mathrm{O} 14-\mathrm{Tb} 1-\mathrm{O} 2$ & $118.55(4)$ & $\mathrm{O} 14-\mathrm{Tb} 1-\mathrm{O} 2$ & 142.17 (3) \\
\hline $\mathrm{O} 22-\mathrm{Tb} 1-\mathrm{O} 2$ & $142.88(5)$ & $\mathrm{O} 22-\mathrm{Tb} 1-\mathrm{O} 2$ & $123.21(3)$ \\
\hline $\mathrm{O} 23-\mathrm{Tb} 1-\mathrm{O} 2$ & 83.39 (4) & $\mathrm{O} 23-\mathrm{Tb} 1-\mathrm{O} 2$ & $125.81(3)$ \\
\hline $\mathrm{O} 24-\mathrm{Tb} 1-\mathrm{O} 2$ & $73.14(4)$ & $\mathrm{O} 24-\mathrm{Tb} 1-\mathrm{O} 2$ & $69.33(3)$ \\
\hline $\mathrm{O} 12-\mathrm{Tb} 1-\mathrm{O} 4$ & $72.71(5)$ & $\mathrm{O} 12-\mathrm{Tb} 1-\mathrm{O} 10$ & $75.77(3)$ \\
\hline $\mathrm{O} 13-\mathrm{Tb} 1-\mathrm{O} 4$ & $92.32(5)$ & $\mathrm{O} 10-\mathrm{Tb} 1-\mathrm{O} 13$ & $141.19(3)$ \\
\hline $\mathrm{O} 14-\mathrm{Tb} 1-\mathrm{O} 4$ & $148.71(4)$ & $\mathrm{O} 14-\mathrm{Tb} 1-\mathrm{O} 10$ & $83.74(3)$ \\
\hline $\mathrm{O} 22-\mathrm{Tb} 1-\mathrm{O} 4$ & $122.01(4)$ & $\mathrm{O} 22-\mathrm{Tb} 1-\mathrm{O} 10$ & $140.58(3)$ \\
\hline $\mathrm{O} 23-\mathrm{Tb} 1-\mathrm{O} 4$ & $136.38(5)$ & $\mathrm{O} 10-\mathrm{Tb} 1-\mathrm{O} 23$ & $70.30(3)$ \\
\hline $\mathrm{O} 24-\mathrm{Tb} 1-\mathrm{O} 4$ & $77.30(5)$ & $\mathrm{O} 10-\mathrm{Tb} 1-\mathrm{O} 24$ & $83.96(3)$ \\
\hline $\mathrm{O} 12-\mathrm{Tb} 1-\mathrm{O} 5$ & $98.74(5)$ & & \\
\hline $\mathrm{O} 13-\mathrm{Tb} 1-\mathrm{O} 5$ & $64.19(5)$ & & \\
\hline $\mathrm{O} 14-\mathrm{Tb} 1-\mathrm{O} 5$ & $131.61(5)$ & & \\
\hline $\mathrm{O} 22-\mathrm{Tb} 1-\mathrm{O} 5$ & $73.45(4)$ & & \\
\hline $\mathrm{O} 23-\mathrm{Tb} 1-\mathrm{O} 5$ & $131.18(4)$ & & \\
\hline $\mathrm{O} 24-\mathrm{Tb} 1-\mathrm{O} 5$ & $71.11(5)$ & & \\
\hline
\end{tabular}

1999; Delangle et al., 2001). The two triangular faces, defined by O10-O12-O14 and O1-O22-O24, are nearly parallel, with a dihedral angle of $5.14^{\circ}$ between the normals to the mean planes. The three rectangular faces, in turn, formed by $\mathrm{O} 1-$ O12-O14-O22, O1-O10-O12-O24 and O10-O14-O22-O24, are capped by $\mathrm{O} 13, \mathrm{O} 2$ and $\mathrm{O} 23$, respectively. In these rectangular faces, the longer $\mathrm{O} \cdots \mathrm{O}$ distance is on average $3.345 \AA$, while the shorter is $2.961 \AA$ (mean value). The alternative geometry of a monocapped square antiprism, as described for $\left[\mathrm{Y}\left(\mathrm{H}_{3} L^{\mathrm{Me}}\right)_{2}\left(\mathrm{NO}_{3}\right)\left(\mathrm{H}_{2} \mathrm{O}\right)\right]\left(\mathrm{NO}_{3}\right)_{2}$ (Chen et al., 1997), appears less suitable to characterize 2 because of a much less regular placement of the coordinating oxygen atoms in the two square planes, O10-O12-O13-O23 and O1-O2$\mathrm{O} 22-\mathrm{O} 24$, that are typical of this polyhedral arrangement.

The coordination of the $\mathrm{Tb}^{\mathrm{III}}$ atom by the two tripodal ligands in both $\mathbf{1}$ and $\boldsymbol{2}$ is very similar. In the $\left[M_{3} M^{\prime}\left(L^{\mathrm{Et}}\right)_{2}(\mathrm{dpm})_{3}\right]$ complexes $\left(M\right.$ and $M^{\prime}=d$-block metals $)$, as above (Accorsi et al., 2006; Totaro et al., 2013; Westrup et al., 2014; Gregoli et al., 2009), the central metal is six-coordinate and the two tripodal ligands are inverted about that atom in an approximately octahedral arrangement; here, the $C_{B} \cdots M$ $\cdots \mathrm{C}_{\mathrm{B}}{ }^{\prime}$ angle is close to $180^{\circ}$ (where $\mathrm{C}_{\mathrm{B}}$ and $\mathrm{C}_{\mathrm{B}}{ }^{\prime}$ are the bridgehead carbon atoms in the tripodal ligand). In our complexes $\mathbf{1}$ and 2, with 10- and 9-coordinate atoms, the tripodal ligands are tilted apart, with $\mathrm{C} 11-\mathrm{Tb} 1-\mathrm{C} 21$ angles of 129.7 and $135.5^{\circ}$, respectively; this arrangement allows more space for the extra ligands in the coordination sphere. In both 1 and 2, all the extra ligands, nitrate ions and water molecules, lie on the plane that bisects the tripodal ligands; the number of extra coordinating atoms determines the distribution in the bisecting plane and overall geometrical patterns, as described above.

According to Table 2, the metal-oxygen distances involving the $\mathrm{H}_{3} L^{\mathrm{Et}}$ ligands in $\mathbf{1}$ and $\mathbf{2}$ vary from 2.3583 (13) to 2.4749 (14) (complex 1) and from 2.3545 (9) to 2.4344 (9) $\AA$ (complex 2), these ranges being slightly larger than those reported for the $\mathrm{Ln}^{3+}$ complexes of the trihydroxycyclohexane ligands (Delangle et al., 2001). This probably arises from the different flexibilities of $\mathrm{H}_{3} L^{\mathrm{Et}}$ and the cyclic alcohols used in the syntheses, which allow for distortions of the lanthanide coordination environments. Also, the more crowded environment of the 10-coordinated metal ion in $\mathbf{1}$ as compared to $\mathbf{2}$ probably causes the larger observed variation.

The $\mathrm{Tb}-\mathrm{O}$ bond lengths involving the nitrate ions in $\mathbf{2}$ are intermediate when compared to the analogous complexes of $\mathrm{Eu}^{\mathrm{III}}, \mathrm{Ho}^{\mathrm{III}}$ and $\mathrm{Yb}^{\mathrm{III}}$ (Delangle et al., 2001; Husson et al., 1999) (Table 3). This is in agreement with the gradual decrease of the effective ionic radii of these ions $(1.120,1.095,1.072$ and $1.042 \AA$ for $\mathrm{Eu}^{\mathrm{III}}, \mathrm{Tb}^{\mathrm{III}}, \mathrm{Ho}^{\mathrm{III}}$ and $\mathrm{Yb}^{\mathrm{III}}$, respectively, in 9coordinate environments; Shannon, 1976). The same pattern is observed for the average metal-oxygen bond of the water molecule (Table 3).

It has been demonstrated (Delangle et al., 2001) that the formation of $\operatorname{Ln}\left(\mathrm{H}_{3} L\right)_{2}$ complexes ( $\mathrm{Ln}=\mathrm{La}^{\mathrm{III}}, \mathrm{Pr}^{\mathrm{III}}, \mathrm{Nd}^{\mathrm{III}}$, $\mathrm{Eu}^{\mathrm{III}}$ and $\mathrm{Yb}^{\mathrm{III}} ; L=$ cis,cis-1,3,5- or cis,cis-1,2,3-trihydroxycyclohexane) in solution is strongly dependent on the metal:ligand ratio and on the chemical nature of the metal ion, its ionic radius, the polarity of the solvent and the nature of the counter-ion, either nitrate or triflate.

In the present work, the reaction between hydrated terbium(III) nitrate and $\mathrm{H}_{3} L^{\mathrm{Et}}$ led to the isolation of two distinct products, $\mathbf{1}$ and $\mathbf{2}$, from the same reaction mixture, with modification only of the crystallization conditions. Product 2, $\left[\mathrm{Tb}\left(\mathrm{H}_{3} L^{\mathrm{Et}}\right)_{2}\left(\mathrm{NO}_{3}\right)\left(\mathrm{H}_{2} \mathrm{O}\right)\right]\left(\mathrm{NO}_{3}\right)_{2}$, was obtained in higher yield and after a shorter time interval $(24 \mathrm{~h})$ than the more symmetrical $1,\left[\mathrm{~Tb}\left(\mathrm{H}_{3} L^{\mathrm{Et}}\right)_{2}\left(\mathrm{NO}_{3}\right)_{2}\right]\left(\mathrm{NO}_{3}\right) \cdot 0.5 \mathrm{glyme}$. The 
Table 3

Bond lengths $(\AA)$ involving the metal cations and the nitrate/water ligands in the lanthanide complexes $\left.\left[\mathrm{Tb}\left(\mathrm{H}_{3} L E \mathrm{Et}\right)_{2}(\mathrm{NO})_{3}\right)\left(\mathrm{H}_{2} \mathrm{O}\right)\right]\left(\mathrm{NO}_{3}\right)_{2}{ }^{a}$ and $\left[\operatorname{Ln}\left(\mathrm{H}_{3} L^{1}\right)\left(\mathrm{NO}_{3}\right)\left(\mathrm{H}_{2} \mathrm{O}\right)\right]\left(\mathrm{NO}_{3}\right)_{2}\left(L n=\mathrm{Eu}^{\mathrm{III}}, \mathrm{Ho}^{\mathrm{III}} \text { and } \mathrm{Yb}^{\mathrm{III}} ; \mathrm{H}_{3} L^{1}=\text { cis,cis-1,3,5-trihydroxycyclohexane }\right)^{b}$.

\begin{tabular}{|c|c|c|c|c|c|}
\hline $\mathrm{Eu}-\mathrm{O}\left(\mathrm{NO}_{3}\right)$ & $2.4869(12)$ & $\mathrm{Eu}-\mathrm{O}\left(\mathrm{NO}_{3}\right)$ & $2.517(2)$ & $\mathrm{Eu}-\mathrm{O}\left(\mathrm{H}_{2} \mathrm{O}\right)$ & $2.4279(14)$ \\
\hline $\mathrm{Tb}-\mathrm{O}\left(\mathrm{NO}_{3}\right)$ & $2.4706(10)$ & $\mathrm{Tb}-\mathrm{O}\left(\mathrm{NO}_{3}\right)$ & $2.4762(9)$ & $\mathrm{Tb}-\mathrm{O}\left(\mathrm{H}_{2} \mathrm{O}\right)$ & $2.3786(9)$ \\
\hline $\mathrm{Yb}-\mathrm{O}\left(\mathrm{NO}_{3}\right)$ & $2.448(6)$ & $\mathrm{Yb}-\mathrm{O}\left(\mathrm{NO}_{3}\right)$ & $2.439(7)$ & $\mathrm{Yb}-\mathrm{O}\left(\mathrm{H}_{2} \mathrm{O}\right)$ & $2.331(7)$ \\
\hline
\end{tabular}

Notes: (a) this work, product 2; (b) Delangle et al. (2001); Husson et al. (1999).

preparation of $\mathbf{2}$ is also easier to reproduce than that of $\mathbf{1}$; the former appears to be favoured by addition of a less polar solvent (hexane) to the reaction mixture. The isolation of $\mathbf{1}$, on the other hand, seems to be subjected to a very subtle control of the crystallization conditions, and this is probably the reason why there are fewer reports of similar, anhydrous $L n\left(\mathrm{H}_{3} L\right)_{2}$ products in the literature. The presence of solvating glyme in the crystals of $\mathbf{1}$ suggests that the use of other solvents with different stereo requirements could be a strategy to help the crystallization of this water-free complex.

\section{Supramolecular features}

The three hydroxyl groups in both complexes are all donor groups to hydrogen bonds. The acceptor atoms are oxygen atoms of nitrate ions and, in complex $\mathbf{1}$, an oxygen atom of the glyme molecule (Fig. 4). In complex 2 , the water ligand forms two hydrogen bonds to two non-coordinating nitrate ions (Fig. 5). Thus, in both compounds, all the ions and the glyme molecule are linked in an extensive three-dimensional hydrogen-bonded network.

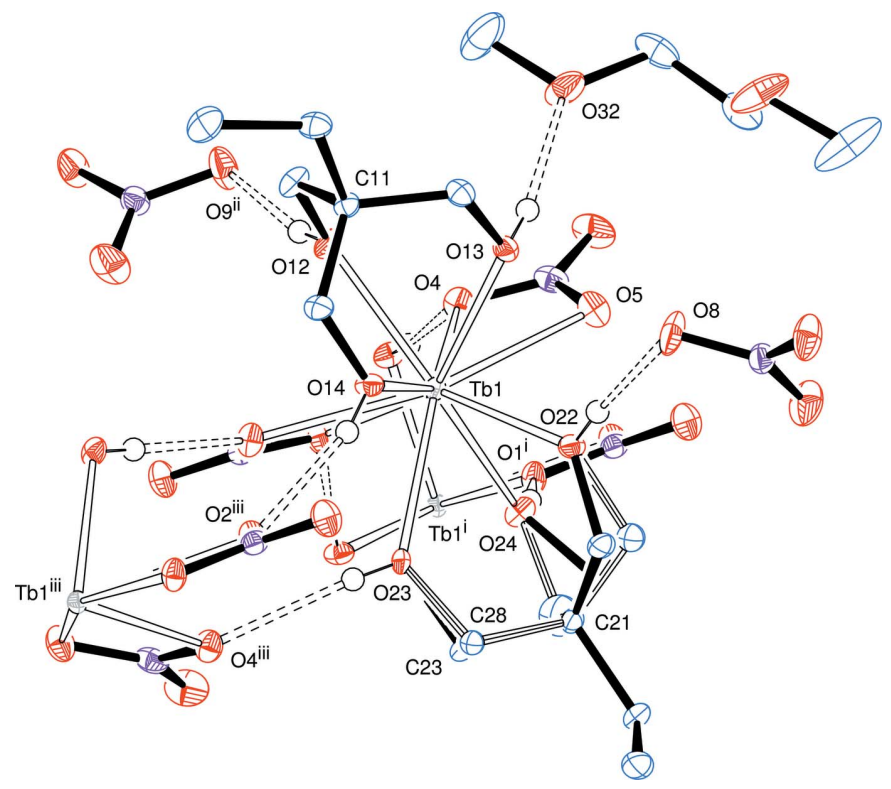

Figure 4

ORTEP representation of hydrogen bonding interactions about the ions and glyme molecule of product $\left.\mathbf{1}, \mathrm{Tb}\left(\mathrm{H}_{3} L^{\mathrm{Et}}\right)_{2}\left(\mathrm{NO}_{3}\right)_{2}\right]\left(\mathrm{NO}_{3}\right) \cdot 0.5 \mathrm{C}_{4} \mathrm{H}_{10} \mathrm{O}_{2}$, with hydrogen bonds indicated by double-dashed lines. Hydrogen atoms on carbon atoms have been omitted for clarity.
In both complexes, there are also some intermolecular $\mathrm{C}-$ $\mathrm{H}$... O interactions, which may be described as 'weak hydrogen bonds'. These are included in Tables 4 and 5 with the stronger $\mathrm{O}-\mathrm{H}$. . O bonds.

\section{Database survey}

Delangle and co-workers (Delangle et al., 2001; Husson et al., 1999) reported the preparation of a variety of mononuclear complexes of various lanthanide(III) ions, specifically $\mathrm{La}^{\mathrm{III}}$, $\mathrm{Pr}^{\mathrm{III}}, \mathrm{Nd}^{\mathrm{III}}, \mathrm{Ho}^{\mathrm{III}}, \mathrm{Eu}^{\mathrm{III}}$ and $\mathrm{Yb}^{\mathrm{III}}$, with the trialcohols cis,cis1,3,5-trihydroxycyclohexane $\left(\mathrm{H}_{3} L^{1}\right)$ and cis,cis-1,2,3-trihydroxycyclohexane $\left(\mathrm{H}_{3} L^{2}\right)$ as models for the coordination of monosaccharides. In those compounds, as in $\mathbf{1}$ and $\mathbf{2}$, the metal atoms are coordinated to two trialcohol molecules and bidentate/monodentate $O$-donor anions (nitrate or triflate), or to these anions and water molecules.

Monosaccharide-derived polyols have also been used as chelating ligands for lanthanide(III) ions. $L n \mathrm{Cl}_{3}$ and $\operatorname{Ln}\left(\mathrm{NO}_{3}\right)_{3}\left(\mathrm{Ln}=\mathrm{La}^{\mathrm{III}}, \mathrm{Tb}^{\mathrm{III}}\right.$ and $\left.\mathrm{Sm}^{\mathrm{III}}\right)$ were shown to form chain-like complexes with D-galactitol in which the alditol provides three hydroxyl groups to coordinate one metal ion and three other hydroxyl groups to coordinate another; in all

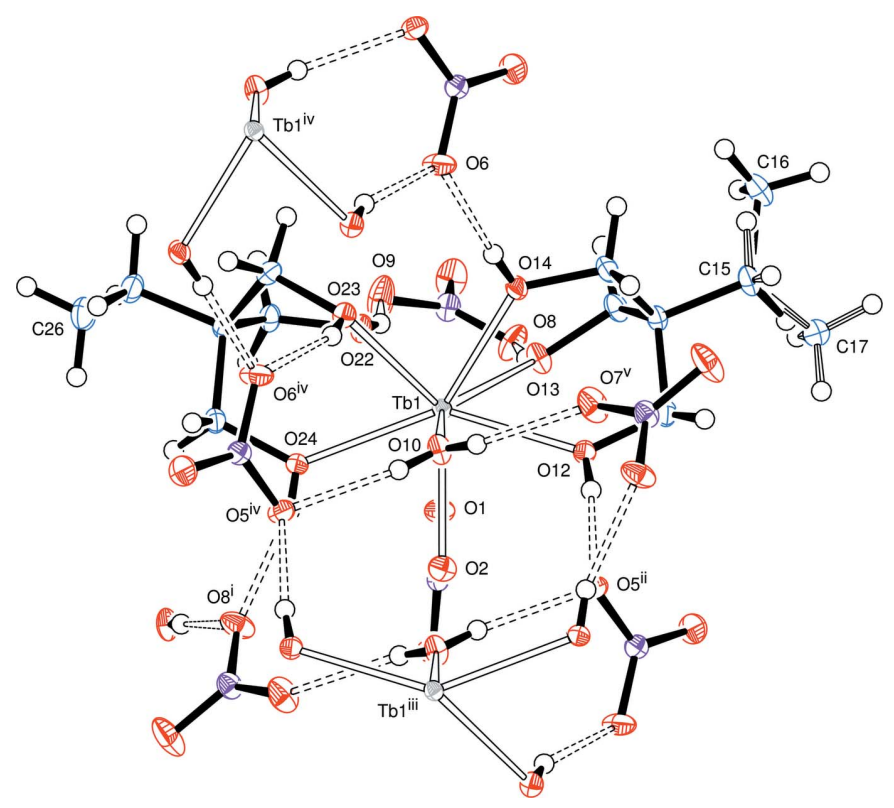

Figure 5

ORTEP representation of hydrogen bonding interactions about the ions of product 2, $\left[\mathrm{Tb}\left(\mathrm{H}_{3} L^{\mathrm{Et}}\right)_{2}\left(\mathrm{NO}_{3}\right)\left(\mathrm{H}_{2} \mathrm{O}\right)\right]\left(\mathrm{NO}_{3}\right)_{2}$, with hydrogen bonds indicated by double-dashed lines. 
Table 4

Hydrogen-bond geometry $\left(\AA{ }^{\circ}\right)$ for $\mathbf{1}$.

\begin{tabular}{lllll}
\hline$D-\mathrm{H} \cdots A$ & $D-\mathrm{H}$ & $\mathrm{H} \cdots A$ & $D \cdots A$ & $D-\mathrm{H} \cdots A$ \\
\hline $\mathrm{O} 12-\mathrm{H} 12 O \cdots \mathrm{O} 9^{\mathrm{i}}$ & $0.72(2)$ & $1.98(2)$ & $2.683(2)$ & $167(3)$ \\
$\mathrm{O} 13-\mathrm{H} 13 O \cdots \mathrm{O} 32$ & $0.74(2)$ & $2.04(2)$ & $2.774(2)$ & $170(3)$ \\
$\mathrm{O} 14-\mathrm{H} 14 O \cdots \mathrm{O} 2^{\mathrm{ii}}$ & $0.74(2)$ & $2.07(3)$ & $2.7935(19)$ & $165(3)$ \\
$\mathrm{O} 22-\mathrm{H} 22 O \cdots \mathrm{O} 8$ & $0.73(2)$ & $2.01(3)$ & $2.735(2)$ & $172(3)$ \\
$\mathrm{O} 23-\mathrm{H} 23 O \cdots 4^{\mathrm{ii}}$ & $0.69(2)$ & $2.16(2)$ & $2.8550(19)$ & $175(2)$ \\
$\mathrm{O} 24-\mathrm{H} 24 O \cdots 1^{\mathrm{iii}}$ & $0.74(3)$ & $1.93(3)$ & $2.6624(19)$ & $171(3)$ \\
$\mathrm{C} 22-\mathrm{H} 22 B \cdots \mathrm{O}^{\text {iv }}$ & 0.99 & 2.44 & $3.358(3)$ & 153 \\
$\mathrm{C} 24-\mathrm{H} 24 B \cdots 7^{\mathrm{v}}$ & 0.99 & 2.49 & $3.220(3)$ & 130 \\
$\mathrm{C} 29-\mathrm{H} 29 A \cdots 7^{\mathrm{v}}$ & 0.99 & 2.41 & $3.27(3)$ & 146 \\
\hline
\end{tabular}

Symmetry codes: (i) $\quad x+\frac{1}{2},-y+1, z ; \quad$ (ii) $\quad-x+1, y-\frac{1}{2},-z+\frac{3}{2}$; $\quad$ (iii) $-x+1, y+\frac{1}{2},-z+\frac{3}{2}$; (iv) $x-\frac{1}{2},-y+1, z ;$ (v) $-x+\frac{1}{2},-y+\frac{3}{2},-z+\frac{3}{2}$.

Table 5

Hydrogen-bond geometry $\left(\AA{ }^{\circ}\right)$ for 2 .

\begin{tabular}{|c|c|c|c|c|}
\hline$D-\mathrm{H} \cdots A$ & $D-\mathrm{H}$ & $\mathrm{H} \cdots A$ & $D \cdots A$ & $D-\mathrm{H} \cdots A$ \\
\hline $\mathrm{O} 10-\mathrm{H} 1 O A \cdots \mathrm{O} 7^{\mathrm{i}}$ & $0.75(2)$ & $2.03(2)$ & $2.7420(14)$ & $159(2)$ \\
\hline $\mathrm{O} 10-\mathrm{H} 1 O B \cdots \mathrm{O} 5^{\mathrm{ii}}$ & $0.79(2)$ & $2.00(2)$ & $2.7703(14)$ & $167(2)$ \\
\hline $\mathrm{O} 13-\mathrm{H} 13 O \cdots \mathrm{O} 8$ & $0.77(2)$ & $1.91(2)$ & $2.6695(14)$ & $169(2)$ \\
\hline $\mathrm{O} 12-\mathrm{H} 12 O \cdots 5^{\mathrm{iii}}$ & $0.74(2)$ & $1.93(2)$ & $2.6713(13)$ & $174(2)$ \\
\hline $\mathrm{O} 14-\mathrm{H} 14 O \cdots \mathrm{O} 6$ & $0.73(2)$ & $1.97(2)$ & $2.6992(14)$ & $174(2)$ \\
\hline $\mathrm{O} 23-\mathrm{H} 23 O \cdots \mathrm{O} 6^{\mathrm{ii}}$ & $0.71(2)$ & $2.09(2)$ & 2.7669 (14) & $161(2)$ \\
\hline $\mathrm{O} 22-\mathrm{H} 22 \mathrm{O} \cdots \mathrm{O} 9$ & $0.76(2)$ & $1.94(2)$ & $2.6609(14)$ & $157(2)$ \\
\hline $\mathrm{O} 24-\mathrm{H} 24 O \cdots \mathrm{O} 8^{\mathrm{iv}}$ & $0.73(2)$ & $1.97(2)$ & $2.6650(14)$ & $158(2)$ \\
\hline $\mathrm{C} 14-\mathrm{H} 14 A \cdots \mathrm{O} 7^{\mathrm{i}}$ & 0.99 & 2.58 & $3.3462(17)$ & 135 \\
\hline $\mathrm{C} 23-\mathrm{H} 23 A \cdots \mathrm{O}^{\mathrm{v}}$ & 0.99 & 2.51 & $3.4003(16)$ & 149 \\
\hline
\end{tabular}

Symmetry codes: (i) $x,-y+\frac{1}{2}, z+\frac{1}{2}$; (ii) $-x+1,-y+1,-z+1$; (iii) $x-1, y$, $z$; (iv) $-x, y+\frac{1}{2},-z+\frac{1}{2}$; (v) $x+1, y, z$.

cases, there are two alditol molecules bound to each lanthanide (Su et al., 2002; Yu et al., 2011). Other authors have employed erythritol, whose molecule functions as two bidentate ligands or as a three-hydroxyl donor to a variety of lanthanide(III) chlorides (Ce, Pr, Nd, Eu, Gd and Tb; Yang et al., 2012; Yang, Xie et al., 2005; Yang, Xu et al., 2005). These studies describe several possible binding modes of these polyols to lanthanide ions.

As far as tripodal alcohol ligands are concerned, mononuclear yttrium(III) complexes of 1,1,1-tris(hydroxymethyl)propane $\left(\mathrm{H}_{3} L^{\mathrm{Et}}\right)$ and 1,1,1-tris(hydroxymethyl)ethane $\left(\mathrm{H}_{3} L^{\mathrm{Me}}\right)$, as well as of the aminopolyalcohol $\left(\mathrm{HOCH}_{2}\right)_{3} \mathrm{CN}\left(\mathrm{CH}_{2} \mathrm{CH}_{2} \mathrm{OH}\right)_{2}, \mathrm{H}_{5} L^{\mathrm{N}(\mathrm{EtOH}) 2}$, were described by Chen and co-workers while investigating chelate complexes for radiotherapeutic applications (Chen et al., 1997). In two of the reported products, those prepared from $\mathrm{H}_{3} L^{\mathrm{Me}}$ and $\mathrm{H}_{5} L^{\mathrm{N}(\mathrm{EtOH}) 2}$, the coordination sphere of the eight-coordinate yttrium atom contains chloride instead of nitrate ligands. A more recent study ( $\mathrm{Xu}$ et al., 2015), in its turn, describes a dysprosium(III) complex with $\mathrm{H}_{3} L^{\mathrm{Et}}$ that is isostructural to product 2 (present work) and has been employed to investigate possible biomedical applications of the binding of rare earth metal ions to the apoferritin protein.

\section{Synthesis and crystallization}

All experimental operations were performed under $\mathrm{N}_{2(\mathrm{~g})}$ (99.999\%, Praxair) or under vacuum of $10^{-3}$ Torr, using Schlenk and glove-box techniques. Solvents (dimethoxy- ethane and hexane) were purified according to procedures described in the literature (Perrin \& Armarego, 1997). Terbium(III) nitrate pentahydrate and 1,1,1-tris(hydroxymethyl)propane $\left(\mathrm{H}_{3} L^{\mathrm{Et}}\right)$ were purchased from Aldrich; the latter was dissolved in thf/toluene (1:1), crystallized at $153 \mathrm{~K}$, isolated by filtration and stored under $\mathrm{N}_{2}$ at room temperature prior to use. Elemental analysis $(\mathrm{C}, \mathrm{H}$ and $\mathrm{N}$ ) were performed under argon by MEDAC Laboratories Ltd. (Chobham, Surrey, UK), using a Thermal Scientific Flash EA 1112 Series Elemental Analyzer. Infrared spectra (FTIR, Nujol mulls) were obtained on a BIORAD FTS 3500GX instrument in the range of $400-4000 \mathrm{~cm}^{-1}$.

\subsection{Synthesis of $\left[\mathrm{Tb}\left(\mathrm{H}_{3} L^{\mathrm{Et}}\right)_{2}\left(\mathrm{NO}_{3}\right)\left(\mathrm{H}_{2} \mathrm{O}\right)\right]\left(\mathrm{NO}_{3}\right)_{2} \cdot 0.5 \mathrm{glyme}$ (product 1)}

A solution containing $1.91 \mathrm{~g}(4.39 \mathrm{mmol})$ of $\mathrm{Tb}\left(\mathrm{NO}_{3}\right)_{3} \cdot-$ $5 \mathrm{H}_{2} \mathrm{O}$ in $50 \mathrm{ml}$ of dimethoxyethane (glyme) received the addition of $1.11 \mathrm{~g}(8.27 \mathrm{mmol})$ of solid 1,1,1-tris(hydroxymethyl)propane to form a colourless solution that was refluxed for $15 \mathrm{~min}$. After this period of time, the heating was turned off and a $32 \mathrm{ml}$ aliquot of the reaction mixture was withdrawn for the isolation of product 2 (described below). The remaining $18 \mathrm{ml}$ were cooled down to $153 \mathrm{~K}$ for four days, without forming any solid. The solution was then dried under vacuum and the resulting solid was almost completely redissolved in $7.5 \mathrm{ml}$ of glyme. A fine suspension was obtained which, after seven days at $153 \mathrm{~K}$, gave colourless crystals that were isolated and dried under vacuum (complex 1). Yield: $360 \mathrm{mg}, 0.547 \mathrm{mmol}(12.5 \%$ based on the total amount of terbium employed in the reaction). If the yield was extrapolated to the total volume of the reaction mixture $(50 \mathrm{ml})$ instead of the $18 \mathrm{ml}$ effectively employed for crystallization, it could reach $34.7 \%$. Elemental analysis: calculated for $\left[\mathrm{Tb}\left(\mathrm{H}_{3} L^{\mathrm{Et}}\right)_{2}\left(\mathrm{NO}_{3}\right)_{2}\right]\left(\mathrm{NO}_{3}\right) \cdot 0.5$ glyme $\quad\left(\mathrm{C}_{14} \mathrm{H}_{33} \mathrm{~N}_{3} \mathrm{O}_{16} \mathrm{~Tb}\right) \quad \mathrm{C}$ 25.54, H 5.05, N 6.38\%. Found C 25.34, H 5.08, N 6.60\%. FTIR (Nujol mull, $\mathrm{cm}^{-1}, s=$ strong, $m=$ medium, $w=$ weak, $s h=$ shoulder): $3359 m, 3220 m v(\mathrm{O}-\mathrm{H})$; 1050sh, 1020s, 942s, mainly $v(\mathrm{C}-\mathrm{O}) ; 1271 s v_{\mathrm{a}}\left(\mathrm{NO}_{2}\right), 1041 s v_{\mathrm{s}}\left(\mathrm{NO}_{2}\right)$.

\subsection{Isolation of $\left[\mathrm{Tb}\left(\mathrm{H}_{3} L^{\mathrm{Et}}\right)_{2}\left(\mathrm{NO}_{3}\right)\left(\mathrm{H}_{2} \mathrm{O}\right)\right]\left(\mathrm{NO}_{3}\right)_{2}$ (product 2)}

The $32 \mathrm{ml}$ aliquot of the reaction mixture described in the synthesis of $\mathbf{1}$ above received the careful addition of a hexane layer $(20 \mathrm{ml})$ at room temperature, and was allowed to stand for $24 \mathrm{~h}$. During this period it was possible to observe the formation of a large number of colourless crystals, which were isolated by filtration and dried under vacuum (complex 2 ). Yield: $1.36 \mathrm{~g}, 2.15 \mathrm{mmol}$ (49.1\% based on the total amount of terbium employed in the reaction). If the yield was extrapolated to the total volume of the reaction mixture $(50 \mathrm{ml})$ instead of $32 \mathrm{ml}$ actually employed for crystallization of $\mathbf{2}$, this yield could reach $76.7 \%$ ). Elemental analysis: calculated for $\mathrm{C}_{12} \mathrm{H}_{30} \mathrm{~N}_{3} \mathrm{O}_{16} \mathrm{~Tb} \mathrm{C} 22.83, \mathrm{H} 4.79, \mathrm{~N} 6.66 \%$. Found C $22.69, \mathrm{H}$ 4.84, N 6.78. FTIR (Nujol mull, $\mathrm{cm}^{-1}$ ): $3475 \mathrm{~m}, 3350 \mathrm{~s}, 3184 \mathrm{~s}$ $v(\mathrm{O}-\mathrm{H}) ; 1620 w \delta(\mathrm{O}-\mathrm{H}), 1050 s, 1035 s, 949 s$, mainly $v(\mathrm{C}-$ $\mathrm{O}) ; 1278 s v_{\mathrm{a}}\left(\mathrm{NO}_{2}\right), 1037 s v_{\mathrm{s}}\left(\mathrm{NO}_{2}\right)$. 
Table 6

Experimental details.

1

Crystal data

Chemical formula

$M_{\mathrm{r}}$

Crystal system, space group

Temperature (K)

$a, b, c(\AA)$

$\beta\left({ }^{\circ}\right)$

$V\left(\AA^{3}\right)$

Z

Radiation type

$\mu\left(\mathrm{mm}^{-1}\right)$

Crystal size (mm)

Data collection

Diffractometer

Absorption correction

$T_{\min }, T_{\max }$

No. of measured, independent and

observed $[I>2 \sigma(I)]$ reflections

$R_{\text {int }}$

$(\sin \theta / \lambda)_{\max }\left(\AA^{-1}\right)$

Refinement

$R\left[F^{2}>2 \sigma\left(F^{2}\right)\right], w R\left(F^{2}\right), S$

No. of reflections

No. of parameters

$\mathrm{H}$-atom treatment

$\Delta \rho_{\max }, \Delta \rho_{\min }\left(\mathrm{e} \AA^{-3}\right)$

\author{
$\left[\mathrm{Tb}\left(\mathrm{NO}_{3}\right)_{2}\left(\mathrm{C}_{6} \mathrm{H}_{14} \mathrm{O}_{3}\right)_{2}\right] \mathrm{NO}_{3} \cdot 0.5 \mathrm{C}_{4} \mathrm{H}_{10} \mathrm{O}_{2}$ \\ 658.35 \\ Monoclinic, $I 2 / a$ \\ 100 \\ 20.1864 (13), 10.2997 (6), 23.832 (2) \\ 108.004 (3) \\ $4712.4(6)$ \\ 8 \\ Mo $K \alpha$ \\ 3.08 \\ $0.14 \times 0.11 \times 0.09$
}

Bruker D8 VENTURE/PHOTON100 CMOS

Multi-scan (SADABS; Bruker, 2014)

$0.694,0.746$

$172878,5889,5031$

0.071

0.670

$0.018,0.036,1.07$

5889

344

$\mathrm{H}$ atoms treated by a mixture of independent and constrained refinement $0.77,-0.54$
2

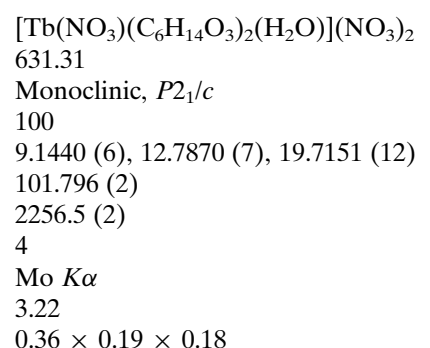

Bruker D8 VENTURE/PHOTON100 CMOS

Multi-scan (SADABS; Bruker, 2014)

$0.636,0.746$

244328, 5629, 5542

0.023

0.670

$0.012,0.029,1.13$

5629

326

$\mathrm{H}$ atoms treated by a mixture of independent and constrained refinement $0.74,-0.26$

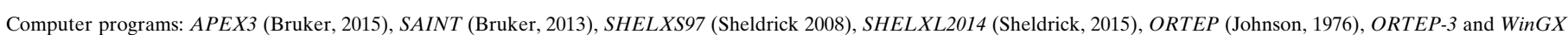
(Farrugia, 2012).

\section{Refinement}

Crystal data, data collection and structure refinement details for both complexes $\mathbf{1}$ and $\mathbf{2}$ are summarized in Table 6 .

Disorder was noted in both structures: in compound $\mathbf{1}$, the methylene groups in the three $\mathrm{CH}_{2} \mathrm{OH}$ groups in one tripodal ligand were each found to be disordered over two sets of sites, with an occupancy ratio of 0.911 (7) : 0.089 (7), whereas in 2, the disorder is in a terminal methyl group, which is disordered over two orientations, with an occupancy ratio of 0.827 (4) : 0.173 (4).

All the hydroxyl and water hydrogen atoms were located clearly in difference maps and were refined freely and satisfactorily. All the remaining hydrogen atoms were set in idealized positions and refined as riding on the parent carbon atoms.

\section{Acknowledgements}

We thank Dr André Luis Rüdiger (UFPR) for his help with the crystal structure resolution of product $\mathbf{2}$. We also gratefully acknowledge the financial support from the Brazilian Research Council (CNPq, grant 307592/2012-0), Coordenação de Aperfeiçoamento de Pessoal de Nível Superior (CAPES, PVE A099/2013 and PNPD 2376/2011), Fundação Araucária (grant 283/2014, protocol 37509) and Universidade Federal do Paraná (UFPR). TG, SOKG, DLH and JFS thank CAPES and $\mathrm{CNPq}$ for research grants and scholarships.

\section{References}

Accorsi, S., Barra, A. L., Caneschi, A., Chastanet, G., Cornia, A., Fabretti, A. C., Gatteschi, D., Mortalo, C., Olivieri, E., Parenti, F., Rosa, P., Sessoli, R., Sorace, L., Wernsdorfer, W. \& Zobbi, L. (2006). J. Am. Chem. Soc. 128, 4742-4755.

Benelli, C. \& Gatteschi, D. (2015). In Introduction to Molecular Magnetism: From Transition Metals to Lanthanides. Weinheim, Germany: Wiley-VCH.

Bruker (2013). SAINT. Bruker AXS Inc., Madison, Wisconsin, USA. Bruker (2014). SADABS. Bruker AXS Inc., Madison, Wisconsin, USA.

Bruker (2015). APEX3. Bruker AXS Inc., Madison, Wisconsin, USA.

Chen, Q., Chang, Y. D. \& Zubieta, J. (1997). Inorg. Chim. Acta, 258, 257-262.

Delangle, P., Husson, C., Lebrun, C., Pécaut, J. \& Vottéro, P. J. A. (2001). Inorg. Chem. 40, 2953-2962.

Farrugia, L. J. (2012). J. Appl. Cryst. 45, 849-854.

Frost, J. M., Harriman, K. L. M. \& Murugesu, M. (2016). Chem. Sci. 7, 2470-2491.

Gatteschi, D., Sessoli, R. \& Villain, J. (2006). In Molecular nanomagnets. Oxford University Press.

Gregoli, L., Danieli, C., Barra, A.-L., Neugebauer, P., Pellegrino, G., Poneti, G., Sessoli, R. \& Cornia, A. (2009). Chem. Eur. J. 15, 64566467.

Husson, C., Delangle, P., Pécaut, J. \& Vottéro, P. J. A. (1999). Inorg. Chem. 38, 2012-2019.

Johnson, C. K. (1976). ORTEP. Report ORNL-5138. Oak Ridge National Laboratory, Tennessee, USA.

Kahn, O. (1997). Nato Advanced Science Institutes Series, Series C, Mathematical and Physical Sciences, Vol. 499, Modular Chemistry, edited by J. Michl, pp. 287-302. 
Liu, J., Chen, Y.-C., Liu, J.-L., Vieru, V., Ungur, L., Jia, J.-H., Chibotaru, L. F., Lan, Y., Wernsdorfer, W., Gao, S., Chen, X.-M. \& Tong, M.-L. (2016). J. Am. Chem. Soc. 138, 5441-5450.

Liu, K., Shi, W. \& Cheng, P. (2015). Coord. Chem. Rev. 289-290, 74122.

Liu, J.-L., Wu, J.-Y., Chen, Y.-C., Mereacre, V., Powell, A. K., Ungur, L., Chibotaru, L. F., Chen, X.-M. \& Tong, M.-L. (2014). Angew. Chem. Int. Ed. 53, 12966-12970.

Luzon, J. \& Sessoli, R. (2012). Dalton Trans. 41, 13556-13567.

Meng, Y. S., Jiang, S. D., Wang, B. W. \& Gao, S. (2016). Acc. Chem. Res. 49, 2381-2389.

Osa, S., Kido, T., Matsumoto, N., Re, N., Pochaba, A. \& Mrozinski, J. (2004). J. Am. Chem. Soc. 126, 420-421.

Perrin, D. D. \& Armarego, W. L. (1997). In Purification of Laboratory Chemicals, 3rd ed. Oxford: Butterworth-Heinemann.

Rohrbaugh, W. J. \& Jacobson, R. A. (1974). Inorg. Chem. 13, 25352539.

Sessoli, R. \& Powell, A. K. (2009). Coord. Chem. Rev. 253, 2328-2341.

Shannon, R. D. (1976). Acta Cryst. A32, 751-767.

Sheldrick, G. M. (2008). Acta Cryst. A64, 112-122.

Sheldrick, G. M. (2015). Acta Cryst. C71, 3-8.

Stumpf, H. O., Pei, Y., Kahn, O., Ouahab, L. \& Grandjean, D. (1993). Science, 261, 447-449.
Su, Y., Yang, L., Jin, X., Weng, S. \& Wu, J. (2002). J. Mol. Struct. 616, 221-230.

Totaro, P., Westrup, K. C. M., Boulon, M.-E., Nunes, G. G., Back, D. F., Barison, A., Ciattini, S., Mannini, M., Sorace, L., Soares, J. F., Cornia, A. \& Sessoli, R. (2013). Dalton Trans. 42, 4416-4426.

Vieru, V., Iwahara, N., Ungur, L. \& Chibotaru, L. F. (2016). Sci. Rep. 6, 24046.

Westrup, K. C. M., Boulon, M. E., Totaro, P., Nunes, G. G., Back, D. F., Barison, A., Jackson, M., Paulsen, C., Gatteschi, D., Sorace, L., Cornia, A., Soares, J. F. \& Sessoli, R. (2014). Chem. Eur. J. 20, 13681-13691.

Xu, Z., Zhang, L., Li, D., Liu, X., Wang, Y. \& Lin, J. (2015). Polyhedron, 92, 37-40.

Yang, L., Hua, X., Xue, J., Pan, Q., Yu, L., Li, W., Xu, Y., Zhao, G., Liu, L., Liu, K., Chen, J. \& Wu, J. (2012). Inorg. Chem. 51, 499-510.

Yang, L., Xie, D., Xu, Y., Wang, Y., Zhang, S., Weng, S., Zhao, K. \& Wu, J. (2005). J. Inorg. Biochem. 99, 1090-1097.

Yang, L., Xu, Y., Wang, Y., Zhang, S., Weng, S., Zhao, K. \& Wu, J. (2005). Carbohydr. Res. 340, 2773-2781.

Yu, L., Hua, X., Pan, Q., Yang, L., Xu, Y., Zhao, G., Wang, H., Wang, H., Wu, J., Liu, K. \& Chen, J. (2011). Carbohydr. Res. 346, 22782284. 


\section{supporting information}

Acta Cryst. (2017). E73, 278-285 [https://doi.org/10.1107/S2056989017001116]

\section{Crystal structures of two mononuclear complexes of terbium(III) nitrate with} the tripodal alcohol 1,1,1-tris(hydroxymethyl)propane

Thaiane Gregório, Siddhartha O. K. Giese, Giovana G. Nunes, Jaísa F. Soares and David L. Hughes

Computing details

For both compounds, data collection: APEX3 (Bruker, 2015); cell refinement: SAINT (Bruker, 2013); data reduction: SAINT (Bruker, 2013); program(s) used to solve structure: SHELXS97 (Sheldrick 2008); program(s) used to refine structure: SHELXL2014 (Sheldrick, 2015); molecular graphics: ORTEP (Johnson, 1976) and ORTEP-3 (Farrugia, 2012); software used to prepare material for publication: SHELXL2014 (Sheldrick, 2015) and WinGX (Farrugia, 2012).

(Compound-1) Dinitratobis[1,1,1-tris(hydroxymethyl)propane]terbium(III) nitrate dimethoxyethane hemisolvate

Crystal data

$\left[\mathrm{Tb}\left(\mathrm{NO}_{3}\right)_{2}\left(\mathrm{C}_{6} \mathrm{H}_{14} \mathrm{O}_{3}\right)_{2}\right] \mathrm{NO}_{3} \cdot 0.5 \mathrm{C}_{4} \mathrm{H}_{10} \mathrm{O}_{2}$

$M_{r}=658.35$

Monoclinic, $I 2 / a$

$a=20.1864(13) \AA$

$b=10.2997(6) \AA$

$c=23.832(2) \AA$

$\beta=108.004(3)^{\circ}$

$V=4712.4(6) \AA^{3}$

$Z=8$

\section{Data collection}

Bruker D8 VENTURE/PHOTON100 CMOS diffractometer

Radiation source: fine-focus sealed tube Graphite monochromator

Detector resolution: 10.4167 pixels $\mathrm{mm}^{-1}$ $\varphi$ and $\omega$ scans

Absorption correction: multi-scan

(SADABS; Bruker, 2014)

$T_{\min }=0.694, T_{\max }=0.746$

\section{Refinement}

Refinement on $F^{2}$

Least-squares matrix: full

$R\left[F^{2}>2 \sigma\left(F^{2}\right)\right]=0.018$

$w R\left(F^{2}\right)=0.036$

$S=1.07$

5889 reflections

344 parameters

0 restraints
$F(000)=2648$

$D_{\mathrm{x}}=1.856 \mathrm{Mg} \mathrm{m}^{-3}$

Mo $K \alpha$ radiation, $\lambda=0.71073 \AA$

Cell parameters from 9404 reflections

$\theta=3.1-28.2^{\circ}$

$\mu=3.08 \mathrm{~mm}^{-1}$

$T=100 \mathrm{~K}$

Fragment, colourless

$0.14 \times 0.11 \times 0.09 \mathrm{~mm}$

172878 measured reflections

5889 independent reflections

5031 reflections with $I>2 \sigma(I)$

$R_{\text {int }}=0.071$

$\theta_{\text {max }}=28.4^{\circ}, \theta_{\min }=2.7^{\circ}$

$h=-26 \rightarrow 26$

$k=-13 \rightarrow 13$

$l=-31 \rightarrow 31$

Primary atom site location: structure-invariant direct methods

Secondary atom site location: difference Fourier map

Hydrogen site location: mixed

$\mathrm{H}$ atoms treated by a mixture of independent and constrained refinement 
$w=1 /\left[\sigma^{2}\left(F_{\mathrm{o}}^{2}\right)+(0.015 P)^{2}+5.6056 P\right]$

where $P=\left(F_{\mathrm{o}}^{2}+2 F_{\mathrm{c}}^{2}\right) / 3$

$(\Delta / \sigma)_{\max }=0.001$

$$
\begin{aligned}
\Delta \rho_{\max } & =0.77 \mathrm{e} \AA^{-3} \\
\Delta \rho=-0.54 & \AA^{-3}
\end{aligned}
$$

\section{Special details}

Geometry. All esds (except the esd in the dihedral angle between two 1.s. planes) are estimated using the full covariance matrix. The cell esds are taken into account individually in the estimation of esds in distances, angles and torsion angles; correlations between esds in cell parameters are only used when they are defined by crystal symmetry. An approximate (isotropic) treatment of cell esds is used for estimating esds involving 1.s. planes.

Fractional atomic coordinates and isotropic or equivalent isotropic displacement parameters $\left(\AA^{2}\right)$

\begin{tabular}{|c|c|c|c|c|c|}
\hline & $x$ & $y$ & $z$ & $U_{\text {iso }} * / U_{\text {eq }}$ & Occ. $(<1)$ \\
\hline Tb1 & $0.41961(2)$ & $0.52548(2)$ & $0.68945(2)$ & $0.00881(3)$ & \\
\hline $\mathrm{C} 11$ & $0.39871(10)$ & $0.29809(17)$ & $0.56884(8)$ & $0.0118(4)$ & \\
\hline $\mathrm{C} 12$ & $0.46190(10)$ & 0.38204 (19) & $0.57107(9)$ & $0.0160(4)$ & \\
\hline H12A & 0.5040 & 0.3266 & 0.5811 & $0.019 *$ & \\
\hline H12B & 0.4555 & 0.4198 & 0.5315 & $0.019 *$ & \\
\hline $\mathrm{O} 12$ & $0.47253(7)$ & $0.48486(14)$ & $0.61340(6)$ & 0.0149 & \\
\hline C13 & $0.33152(10)$ & $0.37790(18)$ & $0.55500(8)$ & 0.0140 & \\
\hline H13A & 0.3195 & 0.4096 & 0.5139 & $0.017 *$ & \\
\hline H13B & 0.2933 & 0.3203 & 0.5576 & $0.017^{*}$ & \\
\hline $\mathrm{O} 13$ & $0.33531(7)$ & $0.48753(14)$ & $0.59343(6)$ & 0.0131 & \\
\hline $\mathrm{C} 14$ & $0.41005(10)$ & $0.21802(18)$ & $0.62473(8)$ & $0.0136(4)$ & \\
\hline H14A & 0.3753 & 0.1471 & 0.6172 & $0.016^{*}$ & \\
\hline H14B & 0.4570 & 0.1784 & 0.6361 & $0.016^{*}$ & \\
\hline O14 & $0.40358(7)$ & $0.29827(13)$ & $0.67214(6)$ & 0.0129 & \\
\hline C15 & $0.38567(10)$ & 0.20335 (19) & $0.51616(8)$ & $0.0169(4)$ & \\
\hline H15A & 0.3415 & 0.1567 & 0.5119 & $0.020 *$ & \\
\hline H15B & 0.3790 & 0.2553 & 0.4799 & $0.020^{*}$ & \\
\hline $\mathrm{C} 16$ & $0.44210(11)$ & $0.1029(2)$ & $0.51961(10)$ & $0.0239(5)$ & \\
\hline H16A & 0.4283 & 0.0486 & 0.4841 & $0.036^{*}$ & \\
\hline H16B & 0.4860 & 0.1471 & 0.5224 & $0.036^{*}$ & \\
\hline $\mathrm{H} 16 \mathrm{C}$ & 0.4483 & 0.0483 & 0.5545 & $0.036^{*}$ & \\
\hline $\mathrm{C} 21$ & $0.34085(9)$ & $0.52402(18)$ & $0.80793(8)$ & $0.0116(3)$ & \\
\hline $\mathrm{C} 22$ & $0.29008(11)$ & 0.4608 & $0.75328(9)$ & $0.0142(6)$ & $0.911(7)$ \\
\hline $\mathrm{H} 22 \mathrm{~A}$ & 0.2903 & 0.3655 & 0.7588 & $0.017^{*}$ & $0.911(7)$ \\
\hline $\mathrm{H} 22 \mathrm{~B}$ & 0.2423 & 0.4928 & 0.7481 & $0.017 *$ & $0.911(7)$ \\
\hline $\mathrm{C} 23$ & $0.40750(13)$ & $0.4457(3)$ & $0.83121(10)$ & $0.0131(6)$ & $0.911(7)$ \\
\hline $\mathrm{H} 23 \mathrm{~A}$ & 0.4426 & 0.4973 & 0.8611 & $0.016^{*}$ & $0.911(7)$ \\
\hline $\mathrm{H} 23 \mathrm{~B}$ & 0.3980 & 0.3658 & 0.8505 & $0.016^{*}$ & $0.911(7)$ \\
\hline $\mathrm{C} 24$ & $0.35697(14)$ & $0.6637(2)$ & $0.79430(12)$ & $0.0152(6)$ & $0.911(7)$ \\
\hline $\mathrm{H} 24 \mathrm{~A}$ & 0.3141 & 0.7049 & 0.7684 & $0.018 *$ & $0.911(7)$ \\
\hline H24B & 0.3727 & 0.7140 & 0.8315 & $0.018^{*}$ & $0.911(7)$ \\
\hline $\mathrm{O} 22$ & $0.30941(7)$ & $0.49039(13)$ & $0.70161(6)$ & 0.0129 & \\
\hline $\mathrm{O} 23$ & $0.43465(7)$ & $0.41116(14)$ & $0.78392(6)$ & 0.0128 & \\
\hline $\mathrm{O} 24$ & $0.41020(7)$ & $0.66656(14)$ & $0.76566(6)$ & $0.0140(3)$ & \\
\hline $\mathrm{C} 25$ & $0.30551(10)$ & $0.5344(2)$ & $0.85686(8)$ & $0.0165(4)$ & \\
\hline $\mathrm{H} 25 \mathrm{~A}$ & 0.3404 & 0.5677 & 0.8930 & $0.020 *$ & \\
\hline
\end{tabular}




\begin{tabular}{|c|c|c|c|c|c|}
\hline $\mathrm{H} 25 \mathrm{~B}$ & 0.2679 & 0.5999 & 0.8444 & $0.020 *$ & \\
\hline $\mathrm{C} 26$ & $0.27454(10)$ & $0.4102(2)$ & $0.87266(9)$ & $0.0207(4)$ & \\
\hline $\mathrm{H} 26 \mathrm{~A}$ & 0.2537 & 0.4284 & 0.9039 & $0.031 *$ & \\
\hline $\mathrm{H} 26 \mathrm{~B}$ & 0.2386 & 0.3773 & 0.8377 & $0.031 *$ & \\
\hline $\mathrm{H} 26 \mathrm{C}$ & 0.3113 & 0.3450 & 0.8865 & $0.031 *$ & \\
\hline $\mathrm{C} 27$ & $0.2836(12)$ & $0.521(3)$ & $0.7509(10)$ & $0.015(6)^{*}$ & $0.089(7)$ \\
\hline $\mathrm{H} 27 \mathrm{~A}$ & 0.2488 & 0.4550 & 0.7530 & $0.018^{*}$ & $0.089(7)$ \\
\hline $\mathrm{H} 27 \mathrm{~B}$ & 0.2601 & 0.6065 & 0.7439 & $0.018^{*}$ & $0.089(7)$ \\
\hline $\mathrm{C} 28$ & $0.3854(14)$ & $0.399(3)$ & $0.8212(11)$ & $0.011(6)^{*}$ & $0.089(7)$ \\
\hline $\mathrm{H} 28 \mathrm{~A}$ & 0.4119 & 0.3927 & 0.8636 & $0.013 *$ & $0.089(7)$ \\
\hline $\mathrm{H} 28 \mathrm{~B}$ & 0.3556 & 0.3206 & 0.8096 & $0.013 *$ & $0.089(7)$ \\
\hline $\mathrm{C} 29$ & $0.387(2)$ & $0.647(3)$ & $0.8196(16)$ & $0.032(8)^{*}$ & $0.089(7)$ \\
\hline $\mathrm{H} 29 \mathrm{~A}$ & 0.3594 & 0.7234 & 0.8254 & $0.039 *$ & $0.089(7)$ \\
\hline H29B & 0.4273 & 0.6362 & 0.8553 & $0.039 *$ & $0.089(7)$ \\
\hline $\mathrm{N} 2$ & 0.39273 (9) & $0.79057(15)$ & $0.63712(7)$ & $0.0162(3)$ & \\
\hline O4 & $0.45380(7)$ & $0.74010(12)$ & $0.65838(6)$ & 0.0164 (3) & \\
\hline O5 & $0.34311(7)$ & $0.72241(13)$ & $0.64212(6)$ & $0.0190(3)$ & \\
\hline O6 & $0.38490(8)$ & $0.89771(13)$ & $0.61430(6)$ & 0.0255 & \\
\hline N1 & $0.57343(8)$ & $0.50126(15)$ & $0.75057(7)$ & 0.0130 & \\
\hline $\mathrm{O} 1$ & $0.53526(7)$ & $0.40279(12)$ & $0.73137(6)$ & 0.0148 & \\
\hline $\mathrm{O} 2$ & $0.54149(7)$ & $0.60919(12)$ & $0.74203(6)$ & $0.0162(3)$ & \\
\hline $\mathrm{O} 3$ & $0.63542(7)$ & $0.49260(14)$ & $0.77547(6)$ & 0.0230 & \\
\hline N3 & $0.13781(8)$ & $0.45279(15)$ & $0.62056(7)$ & $0.0161(3)$ & \\
\hline $\mathrm{O} 7$ & $0.13714(8)$ & $0.54895(15)$ & $0.65113(7)$ & $0.0290(4)$ & \\
\hline O8 & $0.19346(7)$ & $0.41340(15)$ & $0.61347(7)$ & $0.0259(3)$ & \\
\hline O9 & $0.08179(7)$ & $0.39286(14)$ & $0.59578(7)$ & 0.0259 & \\
\hline C31 & $0.27954(11)$ & $0.7871(2)$ & $0.48781(10)$ & 0.0258 & \\
\hline H31A & 0.2616 & 0.7785 & 0.4443 & $0.031^{*}$ & \\
\hline H31B & 0.3048 & 0.8707 & 0.4972 & $0.031 *$ & \\
\hline $\mathrm{O} 32$ & $0.32611(10)$ & $0.68347(15)$ & $0.51152(7)$ & $0.0355(4)$ & \\
\hline C33 & $0.38661(16)$ & $0.6912(3)$ & $0.49237(13)$ & $0.0530(9)$ & \\
\hline H33A & 0.4180 & 0.6188 & 0.5092 & $0.079 *$ & \\
\hline H33B & 0.3726 & 0.6864 & 0.4492 & $0.079 *$ & \\
\hline $\mathrm{H} 33 \mathrm{C}$ & 0.4107 & 0.7735 & 0.5055 & $0.079 *$ & \\
\hline $\mathrm{H} 12 \mathrm{O}$ & $0.5042(13)$ & $0.518(2)$ & $0.6139(11)$ & $0.019(6)^{*}$ & \\
\hline H13O & $0.3300(12)$ & $0.544(2)$ & $0.5736(11)$ & $0.021(7)^{*}$ & \\
\hline H14O & $0.4146(12)$ & $0.255(2)$ & 0.6983 (11) & $0.026(7)^{*}$ & \\
\hline $\mathrm{H} 22 \mathrm{O}$ & $0.2797(13)$ & $0.473(2)$ & $0.6760(11)$ & $0.022(7)^{*}$ & \\
\hline $\mathrm{H} 23 \mathrm{O}$ & $0.4631(12)$ & $0.371(2)$ & $0.7967(10)$ & $0.013(6)^{*}$ & \\
\hline $\mathrm{H} 24 \mathrm{O}$ & $0.4214(13)$ & $0.735(3)$ & $0.7651(11)$ & $0.030(8)^{*}$ & \\
\hline
\end{tabular}

Atomic displacement parameters $\left(\AA^{2}\right)$

\begin{tabular}{lllllll}
\hline & $U^{11}$ & $U^{22}$ & $U^{33}$ & $U^{12}$ & $U^{13}$ & $U^{23}$ \\
\hline $\mathrm{Tb} 1$ & $0.00815(4)$ & $0.00833(4)$ & $0.01016(4)$ & $-0.00074(4)$ & $0.00313(3)$ & $-0.00065(4)$ \\
$\mathrm{C} 11$ & $0.0138(9)$ & $0.0102(9)$ & $0.0119(9)$ & $-0.0002(7)$ & $0.0047(7)$ & $-0.0012(7)$ \\
$\mathrm{C} 12$ & $0.0169(10)$ & $0.0159(10)$ & $0.0182(10)$ & $-0.0023(8)$ & $0.0101(8)$ & $-0.0046(8)$ \\
$\mathrm{O} 12$ & $0.0120(7)$ & $0.0175(7)$ & $0.0177(7)$ & $-0.0066(6)$ & $0.0084(6)$ & $-0.0060(6)$
\end{tabular}




\begin{tabular}{|c|c|c|c|c|c|c|}
\hline $\mathrm{C} 13$ & $0.0147(9)$ & $0.0129(9)$ & $0.0124(9)$ & $-0.0012(7)$ & $0.0011(7)$ & $-0.0019(7)$ \\
\hline $\mathrm{O} 13$ & $0.0141(7)$ & $0.0121(7)$ & $0.0125(7)$ & $0.0023(5)$ & $0.0032(5)$ & $0.0014(6)$ \\
\hline $\mathrm{C} 14$ & $0.0192(10)$ & $0.0099(9)$ & $0.0114(9)$ & $0.0007(7)$ & $0.0041(8)$ & $-0.0029(7)$ \\
\hline $\mathrm{O} 14$ & $0.0190(7)$ & $0.0103(7)$ & $0.0103(7)$ & $0.0005(5)$ & $0.0057(6)$ & $0.0005(5)$ \\
\hline C15 & $0.0221(10)$ & $0.0155(10)$ & $0.0124(9)$ & $-0.0016(8)$ & $0.0042(8)$ & $-0.0032(7)$ \\
\hline $\mathrm{C} 16$ & $0.0303(12)$ & $0.0196(11)$ & $0.0241(11)$ & $0.0009(9)$ & $0.0118(10)$ & $-0.0079(9)$ \\
\hline $\mathrm{C} 21$ & $0.0110(8)$ & $0.0124(8)$ & $0.0128(9)$ & $0.0010(7)$ & $0.0055(7)$ & $0.0006(8)$ \\
\hline $\mathrm{C} 22$ & $0.0124(10)$ & $0.0181(16)$ & $0.0134(11)$ & $-0.0013(9)$ & $0.0061(8)$ & $0.0014(9)$ \\
\hline $\mathrm{C} 23$ & 0.0127 (11) & $0.0166(14)$ & $0.0120(11)$ & $0.0006(10)$ & $0.0068(9)$ & $0.0002(9)$ \\
\hline $\mathrm{C} 24$ & $0.0184(13)$ & $0.0124(11)$ & 0.0193 (14) & $0.0000(9)$ & $0.0123(11)$ & -0.0014 \\
\hline $\mathrm{O} 22$ & $0.0095(6)$ & $0.0187(7)$ & $0.0100(6)$ & $-0.0025(5)$ & $0.0023(5)$ & $-0.0001(5)$ \\
\hline $\mathrm{O} 23$ & $0.0121(7)$ & $0.0145(7)$ & $0.0130(7)$ & $0.0068(6)$ & $0.0054(6)$ & $0.0023(6)$ \\
\hline $\mathrm{O} 24$ & 0.0177 (7) & $0.0089(7)$ & $0.0183(7)$ & $-0.0036(6)$ & $0.0097(6)$ & $-0.0017(5)$ \\
\hline $\mathrm{C} 25$ & $0.0159(9)$ & $0.0225(10)$ & $0.0133(9)$ & $0.0032(8)$ & $0.0078(7)$ & $-0.0008(8)$ \\
\hline $\mathrm{C} 26$ & $0.0161(10)$ & $0.0303(12)$ & $0.0174(10)$ & $0.0005(9)$ & $0.0073(8)$ & $0.0066(9)$ \\
\hline N2 & $0.0232(9)$ & $0.0114(8)$ & $0.0118(8)$ & $-0.0009(7)$ & $0.0022(7)$ & $-0.0012(6)$ \\
\hline $\mathrm{O} 4$ & $0.0175(7)$ & $0.0123(7)$ & $0.0202(7)$ & $-0.0008(5)$ & $0.0070(6)$ & $0.0003(5)$ \\
\hline O5 & $0.0174(7)$ & $0.0143(7)$ & $0.0224(7)$ & $-0.0022(6)$ & $0.0019(6)$ & $0.0012(6)$ \\
\hline O6 & $0.0418(10)$ & $0.0099(7)$ & $0.0229(8)$ & $0.0022(6)$ & $0.0071(7)$ & $0.0055(6)$ \\
\hline N1 & $0.0133(8)$ & $0.0153(9)$ & $0.0110(7)$ & $0.0010(6)$ & $0.0047(6)$ & $0.0014(6)$ \\
\hline $\mathrm{O} 1$ & 0.0137 (7) & $0.0100(7)$ & $0.0217(7)$ & $-0.0011(5)$ & $0.0070(6)$ & $-0.0012(5)$ \\
\hline $\mathrm{O} 2$ & $0.0142(7)$ & $0.0118(7)$ & $0.0208(7)$ & $0.0016(5)$ & $0.0025(6)$ & $-0.0004(5)$ \\
\hline $\mathrm{O} 3$ & $0.0102(7)$ & $0.0329(9)$ & $0.0228(8)$ & $0.0021(6)$ & $0.0005(6)$ & $0.0012(6)$ \\
\hline N3 & $0.0134(8)$ & $0.0182(9)$ & $0.0159(8)$ & $0.0013(6)$ & $0.0034(7)$ & $-0.0021(6)$ \\
\hline $\mathrm{O} 7$ & $0.0255(8)$ & $0.0269(9)$ & $0.0339(9)$ & $0.0024(6)$ & $0.0080(7)$ & $-0.0160(7)$ \\
\hline O8 & $0.0113(7)$ & 0.0347 (9) & $0.0321(9)$ & $0.0014(6)$ & $0.0073(6)$ & $-0.0159(7)$ \\
\hline O9 & $0.0124(7)$ & $0.0275(8)$ & $0.0363(9)$ & $-0.0021(6)$ & $0.0053(7)$ & $-0.0127(7)$ \\
\hline $\mathrm{C} 31$ & $0.0334(13)$ & $0.0159(10)$ & $0.0204(11)$ & $-0.0028(9)$ & $-0.0029(9)$ & $0.0044(8)$ \\
\hline $\mathrm{O} 32$ & $0.0599(12)$ & $0.0252(9)$ & $0.0351(9)$ & $0.0212(8)$ & $0.0351(9)$ & $0.0164(7)$ \\
\hline C33 & $0.080(2)$ & $0.0396(16)$ & $0.065(2)$ & $0.0328(15)$ & $0.0601(18)$ & $0.0299(14)$ \\
\hline
\end{tabular}

Geometric parameters $\left(\AA,{ }^{o}\right)$

\begin{tabular}{llll}
\hline Tb1-O22 & $2.3583(13)$ & $\mathrm{C} 23-\mathrm{O} 23$ & $1.442(2)$ \\
$\mathrm{Tb} 1-\mathrm{O} 24$ & $2.3790(13)$ & $\mathrm{C} 23-\mathrm{H} 23 \mathrm{~A}$ & 0.9900 \\
$\mathrm{~Tb} 1-\mathrm{O} 14$ & $2.3810(13)$ & $\mathrm{C} 23-\mathrm{H} 23 \mathrm{~B}$ & 0.9900 \\
$\mathrm{~Tb} 1-\mathrm{O} 12$ & $2.4078(13)$ & $\mathrm{C} 24-\mathrm{O} 24$ & $1.440(2)$ \\
$\mathrm{Tb} 1-\mathrm{O} 13$ & $2.4245(13)$ & $\mathrm{C} 24-\mathrm{H} 24 \mathrm{~A}$ & 0.9900 \\
$\mathrm{~Tb} 1-\mathrm{O} 23$ & $2.4749(14)$ & $\mathrm{C} 24-\mathrm{H} 24 \mathrm{~B}$ & 0.9900 \\
$\mathrm{~Tb} 1-\mathrm{O} 4$ & $2.4953(13)$ & $\mathrm{O} 22-\mathrm{C} 27$ & $1.46(2)$ \\
$\mathrm{Tb} 1-\mathrm{O} 2$ & $2.5418(13)$ & $\mathrm{O} 22-\mathrm{H} 22 \mathrm{O}$ & $0.73(2)$ \\
$\mathrm{Tb} 1-\mathrm{O} 1$ & $2.5697(13)$ & $\mathrm{O} 23-\mathrm{C} 28$ & $1.53(2)$ \\
$\mathrm{Tb} 1-\mathrm{O} 5$ & $2.5874(14)$ & $\mathrm{O} 23-\mathrm{H} 23 \mathrm{O}$ & $0.69(2)$ \\
$\mathrm{C} 11-\mathrm{C} 14$ & $1.523(2)$ & $\mathrm{O} 24-\mathrm{C} 29$ & $1.52(3)$ \\
$\mathrm{C} 11-\mathrm{C} 12$ & $1.528(3)$ & $\mathrm{O} 24-\mathrm{H} 24 \mathrm{O}$ & $0.74(3)$ \\
$\mathrm{C} 11-\mathrm{C} 13$ & $1.532(3)$ & $\mathrm{C} 25-\mathrm{C} 26$ & $1.521(3)$ \\
$\mathrm{C} 11-\mathrm{C} 15$ & $1.547(3)$ & $\mathrm{C} 25-\mathrm{H} 25 \mathrm{~A}$ & 0.9900 \\
$\mathrm{C} 12-\mathrm{O} 12$ & $1.432(2)$ & $\mathrm{C} 25-\mathrm{H} 25 \mathrm{~B}$ & 0.9900
\end{tabular}




\begin{tabular}{|c|c|c|c|}
\hline $\mathrm{C} 12-\mathrm{H} 12 \mathrm{~A}$ & 0.9900 & $\mathrm{C} 26-\mathrm{H} 26 \mathrm{~A}$ & 0.9800 \\
\hline $\mathrm{C} 12-\mathrm{H} 12 \mathrm{~B}$ & 0.9900 & $\mathrm{C} 26-\mathrm{H} 26 \mathrm{~B}$ & 0.9800 \\
\hline $\mathrm{O} 12-\mathrm{H} 12 \mathrm{O}$ & $0.72(2)$ & $\mathrm{C} 26-\mathrm{H} 26 \mathrm{C}$ & 0.9800 \\
\hline $\mathrm{C} 13-\mathrm{O} 13$ & $1.441(2)$ & $\mathrm{C} 27-\mathrm{H} 27 \mathrm{~A}$ & 0.9900 \\
\hline C13-H13A & 0.9900 & $\mathrm{C} 27-\mathrm{H} 27 \mathrm{~B}$ & 0.9900 \\
\hline $\mathrm{C} 13-\mathrm{H} 13 \mathrm{~B}$ & 0.9900 & $\mathrm{C} 28-\mathrm{H} 28 \mathrm{~A}$ & 0.9900 \\
\hline $\mathrm{O} 13-\mathrm{H} 13 \mathrm{O}$ & $0.74(2)$ & $\mathrm{C} 28-\mathrm{H} 28 \mathrm{~B}$ & 0.9900 \\
\hline $\mathrm{C} 14-\mathrm{O} 14$ & $1.438(2)$ & $\mathrm{C} 29-\mathrm{H} 29 \mathrm{~A}$ & 0.9900 \\
\hline $\mathrm{C} 14-\mathrm{H} 14 \mathrm{~A}$ & 0.9900 & $\mathrm{C} 29-\mathrm{H} 29 \mathrm{~B}$ & 0.9900 \\
\hline C14-H14B & 0.9900 & $\mathrm{~N} 2-\mathrm{O} 6$ & $1.219(2)$ \\
\hline $\mathrm{O} 14-\mathrm{H} 14 \mathrm{O}$ & $0.74(2)$ & $\mathrm{N} 2-\mathrm{O} 5$ & $1.259(2)$ \\
\hline $\mathrm{C} 15-\mathrm{C} 16$ & $1.522(3)$ & $\mathrm{N} 2-\mathrm{O} 4$ & $1.289(2)$ \\
\hline $\mathrm{C} 15-\mathrm{H} 15 \mathrm{~A}$ & 0.9900 & $\mathrm{~N} 1-\mathrm{O} 3$ & $1.211(2)$ \\
\hline C15-H15B & 0.9900 & $\mathrm{~N} 1-\mathrm{O} 2$ & $1.2696(19)$ \\
\hline $\mathrm{C} 16-\mathrm{H} 16 \mathrm{~A}$ & 0.9800 & $\mathrm{~N} 1-\mathrm{O} 1$ & $1.270(2)$ \\
\hline C16-H16B & 0.9800 & $\mathrm{~N} 3-\mathrm{O} 7$ & $1.232(2)$ \\
\hline $\mathrm{C} 16-\mathrm{H} 16 \mathrm{C}$ & 0.9800 & $\mathrm{~N} 3-\mathrm{O} 8$ & $1.254(2)$ \\
\hline $\mathrm{C} 21-\mathrm{C} 27$ & $1.49(2)$ & $\mathrm{N} 3-\mathrm{O} 9$ & $1.263(2)$ \\
\hline $\mathrm{C} 21-\mathrm{C} 23$ & $1.519(3)$ & $\mathrm{C} 31-\mathrm{O} 32$ & $1.419(3)$ \\
\hline $\mathrm{C} 21-\mathrm{C} 24$ & $1.532(3)$ & $\mathrm{C} 31-\mathrm{C} 31^{\mathrm{i}}$ & $1.479(5)$ \\
\hline $\mathrm{C} 21-\mathrm{C} 22$ & $1.532(3)$ & $\mathrm{C} 31-\mathrm{H} 31 \mathrm{~A}$ & 0.9900 \\
\hline $\mathrm{C} 21-\mathrm{C} 29$ & $1.54(3)$ & $\mathrm{C} 31-\mathrm{H} 31 \mathrm{~B}$ & 0.9900 \\
\hline $\mathrm{C} 21-\mathrm{C} 25$ & $1.547(2)$ & $\mathrm{O} 32-\mathrm{C} 33$ & $1.432(3)$ \\
\hline $\mathrm{C} 21-\mathrm{C} 28$ & $1.55(2)$ & $\mathrm{C} 33-\mathrm{H} 33 \mathrm{~A}$ & 0.9800 \\
\hline $\mathrm{C} 22-\mathrm{O} 22$ & $1.435(2)$ & $\mathrm{C} 33-\mathrm{H} 33 \mathrm{~B}$ & 0.9800 \\
\hline $\mathrm{C} 22-\mathrm{H} 22 \mathrm{~A}$ & 0.9900 & $\mathrm{C} 33-\mathrm{H} 33 \mathrm{C}$ & 0.9800 \\
\hline $\mathrm{C} 22-\mathrm{H} 22 \mathrm{~B}$ & 0.9900 & & \\
\hline $\mathrm{O} 22-\mathrm{Tb} 1-\mathrm{O} 24$ & $72.47(5)$ & $\mathrm{C} 24-\mathrm{C} 21-\mathrm{C} 25$ & $105.80(15)$ \\
\hline $\mathrm{O} 22-\mathrm{Tb} 1-\mathrm{O} 14$ & $77.75(5)$ & $\mathrm{C} 22-\mathrm{C} 21-\mathrm{C} 25$ & $109.09(15)$ \\
\hline $\mathrm{O} 24-\mathrm{Tb} 1-\mathrm{O} 14$ & $133.94(5)$ & $\mathrm{C} 29-\mathrm{C} 21-\mathrm{C} 25$ & $101.4(11)$ \\
\hline $\mathrm{O} 22-\mathrm{Tb} 1-\mathrm{O} 12$ & $136.11(5)$ & $\mathrm{C} 27-\mathrm{C} 21-\mathrm{C} 28$ & $114.0(14)$ \\
\hline $\mathrm{O} 24-\mathrm{Tb} 1-\mathrm{O} 12$ & $147.08(5)$ & $\mathrm{C} 29-\mathrm{C} 21-\mathrm{C} 28$ & $111.8(16)$ \\
\hline $\mathrm{O} 14-\mathrm{Tb} 1-\mathrm{O} 12$ & $76.53(5)$ & $\mathrm{C} 25-\mathrm{C} 21-\mathrm{C} 28$ & $106.2(9)$ \\
\hline $\mathrm{O} 22-\mathrm{Tb} 1-\mathrm{O} 13$ & $71.20(5)$ & $\mathrm{O} 22-\mathrm{C} 22-\mathrm{C} 21$ & $110.57(16)$ \\
\hline $\mathrm{O} 24-\mathrm{Tb} 1-\mathrm{O} 13$ & $128.37(5)$ & $\mathrm{O} 22-\mathrm{C} 22-\mathrm{H} 22 \mathrm{~A}$ & 109.5 \\
\hline $\mathrm{O} 14-\mathrm{Tb} 1-\mathrm{O} 13$ & $70.11(5)$ & $\mathrm{C} 21-\mathrm{C} 22-\mathrm{H} 22 \mathrm{~A}$ & 109.5 \\
\hline $\mathrm{O} 12-\mathrm{Tb} 1-\mathrm{O} 13$ & $66.85(5)$ & $\mathrm{O} 22-\mathrm{C} 22-\mathrm{H} 22 \mathrm{~B}$ & 109.5 \\
\hline $\mathrm{O} 22-\mathrm{Tb} 1-\mathrm{O} 23$ & $70.76(5)$ & $\mathrm{C} 21-\mathrm{C} 22-\mathrm{H} 22 \mathrm{~B}$ & 109.5 \\
\hline $\mathrm{O} 24-\mathrm{Tb} 1-\mathrm{O} 23$ & $67.19(5)$ & $\mathrm{H} 22 \mathrm{~A}-\mathrm{C} 22-\mathrm{H} 22 \mathrm{~B}$ & 108.1 \\
\hline $\mathrm{O} 14-\mathrm{Tb} 1-\mathrm{O} 23$ & $70.24(5)$ & $\mathrm{O} 23-\mathrm{C} 23-\mathrm{C} 21$ & $110.69(16)$ \\
\hline $\mathrm{O} 12-\mathrm{Tb} 1-\mathrm{O} 23$ & $130.08(5)$ & $\mathrm{O} 23-\mathrm{C} 23-\mathrm{H} 23 \mathrm{~A}$ & 109.5 \\
\hline $\mathrm{O} 13-\mathrm{Tb} 1-\mathrm{O} 23$ & $129.41(5)$ & $\mathrm{C} 21-\mathrm{C} 23-\mathrm{H} 23 \mathrm{~A}$ & 109.5 \\
\hline $\mathrm{O} 22-\mathrm{Tb} 1-\mathrm{O} 4$ & $122.01(4)$ & $\mathrm{O} 23-\mathrm{C} 23-\mathrm{H} 23 \mathrm{~B}$ & 109.5 \\
\hline $\mathrm{O} 24-\mathrm{Tb} 1-\mathrm{O} 4$ & $77.30(5)$ & $\mathrm{C} 21-\mathrm{C} 23-\mathrm{H} 23 \mathrm{~B}$ & 109.5 \\
\hline $\mathrm{O} 14-\mathrm{Tb} 1-\mathrm{O} 4$ & $148.71(4)$ & $\mathrm{H} 23 \mathrm{~A}-\mathrm{C} 23-\mathrm{H} 23 \mathrm{~B}$ & 108.1 \\
\hline $\mathrm{O} 12-\mathrm{Tb} 1-\mathrm{O} 4$ & $72.71(5)$ & $\mathrm{O} 24-\mathrm{C} 24-\mathrm{C} 21$ & $111.00(16)$ \\
\hline $\mathrm{O} 13-\mathrm{Tb} 1-\mathrm{O} 4$ & $92.32(5)$ & $\mathrm{O} 24-\mathrm{C} 24-\mathrm{H} 24 \mathrm{~A}$ & 109.4 \\
\hline
\end{tabular}




\begin{tabular}{|c|c|}
\hline $\mathrm{O} 23-\mathrm{Tb} 1-\mathrm{O} 4$ & $136.38(5)$ \\
\hline $\mathrm{O} 22-\mathrm{Tb} 1-\mathrm{O} 2$ & $142.88(5)$ \\
\hline $\mathrm{O} 24-\mathrm{Tb} 1-\mathrm{O} 2$ & $73.14(4)$ \\
\hline $\mathrm{O} 14-\mathrm{Tb} 1-\mathrm{O} 2$ & $118.55(4)$ \\
\hline $\mathrm{O} 12-\mathrm{Tb} 1-\mathrm{O} 2$ & $80.97(5)$ \\
\hline $\mathrm{O} 13-\mathrm{Tb} 1-\mathrm{O} 2$ & $144.10(5)$ \\
\hline $\mathrm{O} 23-\mathrm{Tb} 1-\mathrm{O} 2$ & $83.39(4)$ \\
\hline $\mathrm{O} 4-\mathrm{Tb} 1-\mathrm{O} 2$ & $62.06(4)$ \\
\hline $\mathrm{O} 22-\mathrm{Tb} 1-\mathrm{O} 1$ & $130.92(4)$ \\
\hline $\mathrm{O} 24-\mathrm{Tb} 1-\mathrm{O} 1$ & $106.31(4)$ \\
\hline $\mathrm{O} 14-\mathrm{Tb} 1-\mathrm{O} 1$ & $69.06(4)$ \\
\hline $\mathrm{O} 12-\mathrm{Tb} 1-\mathrm{O} 1$ & $69.27(4)$ \\
\hline $\mathrm{O} 13-\mathrm{Tb} 1-\mathrm{O} 1$ & $125.17(4)$ \\
\hline $\mathrm{O} 23-\mathrm{Tb} 1-\mathrm{O} 1$ & $64.60(4)$ \\
\hline $\mathrm{O} 4-\mathrm{Tb} 1-\mathrm{O} 1$ & $104.45(4)$ \\
\hline $\mathrm{O} 2-\mathrm{Tb} 1-\mathrm{O} 1$ & $49.50(4)$ \\
\hline $\mathrm{O} 22-\mathrm{Tb} 1-\mathrm{O} 5$ & $73.45(4)$ \\
\hline $\mathrm{O} 24-\mathrm{Tb} 1-\mathrm{O} 5$ & $71.11(5)$ \\
\hline $\mathrm{O} 14-\mathrm{Tb} 1-\mathrm{O} 5$ & $131.61(5)$ \\
\hline $\mathrm{O} 12-\mathrm{Tb} 1-\mathrm{O} 5$ & $98.74(5)$ \\
\hline $\mathrm{O} 13-\mathrm{Tb} 1-\mathrm{O} 5$ & $64.19(5)$ \\
\hline $\mathrm{O} 23-\mathrm{Tb} 1-\mathrm{O} 5$ & $131.18(4)$ \\
\hline $\mathrm{O} 4-\mathrm{Tb} 1-\mathrm{O} 5$ & $50.12(4)$ \\
\hline $\mathrm{O} 2-\mathrm{Tb} 1-\mathrm{O} 5$ & $107.78(4)$ \\
\hline $\mathrm{O} 1-\mathrm{Tb} 1-\mathrm{O} 5$ & $154.57(4)$ \\
\hline $\mathrm{C} 14-\mathrm{C} 11-\mathrm{C} 12$ & $112.20(16)$ \\
\hline $\mathrm{C} 14-\mathrm{C} 11-\mathrm{C} 13$ & $111.26(15)$ \\
\hline $\mathrm{C} 12-\mathrm{C} 11-\mathrm{C} 13$ & $112.19(15)$ \\
\hline $\mathrm{C} 14-\mathrm{C} 11-\mathrm{C} 15$ & $108.07(15)$ \\
\hline $\mathrm{C} 12-\mathrm{C} 11-\mathrm{C} 15$ & $108.42(15)$ \\
\hline $\mathrm{C} 13-\mathrm{C} 11-\mathrm{C} 15$ & $104.27(15)$ \\
\hline $\mathrm{O} 12-\mathrm{C} 12-\mathrm{C} 11$ & $112.61(15)$ \\
\hline $\mathrm{O} 12-\mathrm{C} 12-\mathrm{H} 12 \mathrm{~A}$ & 109.1 \\
\hline $\mathrm{C} 11-\mathrm{C} 12-\mathrm{H} 12 \mathrm{~A}$ & 109.1 \\
\hline $\mathrm{O} 12-\mathrm{C} 12-\mathrm{H} 12 \mathrm{~B}$ & 109.1 \\
\hline $\mathrm{C} 11-\mathrm{C} 12-\mathrm{H} 12 \mathrm{~B}$ & 109.1 \\
\hline $\mathrm{H} 12 \mathrm{~A}-\mathrm{C} 12-\mathrm{H} 12 \mathrm{~B}$ & 107.8 \\
\hline $\mathrm{C} 12-\mathrm{O} 12-\mathrm{Tb} 1$ & $130.84(11)$ \\
\hline $\mathrm{C} 12-\mathrm{O} 12-\mathrm{H} 12 \mathrm{O}$ & $107.4(19)$ \\
\hline $\mathrm{Tb} 1-\mathrm{O} 12-\mathrm{H} 12 \mathrm{O}$ & $120.2(19)$ \\
\hline $\mathrm{O} 13-\mathrm{C} 13-\mathrm{C} 11$ & $114.46(15)$ \\
\hline $\mathrm{O} 13-\mathrm{C} 13-\mathrm{H} 13 \mathrm{~A}$ & 108.6 \\
\hline $\mathrm{C} 11-\mathrm{C} 13-\mathrm{H} 13 \mathrm{~A}$ & 108.6 \\
\hline $\mathrm{O} 13-\mathrm{C} 13-\mathrm{H} 13 \mathrm{~B}$ & 108.6 \\
\hline $\mathrm{C} 11-\mathrm{C} 13-\mathrm{H} 13 \mathrm{~B}$ & 108.6 \\
\hline $\mathrm{H} 13 \mathrm{~A}-\mathrm{C} 13-\mathrm{H} 13 \mathrm{~B}$ & 107.6 \\
\hline $\mathrm{C} 13-\mathrm{O} 13-\mathrm{Tb} 1$ & $127.60(11)$ \\
\hline & \\
\hline
\end{tabular}

\begin{tabular}{|c|c|}
\hline $\mathrm{C} 21-\mathrm{C} 24-\mathrm{H} 24 \mathrm{~A}$ & 109.4 \\
\hline $\mathrm{O} 24-\mathrm{C} 24-\mathrm{H} 24 \mathrm{~B}$ & 109.4 \\
\hline $\mathrm{C} 21-\mathrm{C} 24-\mathrm{H} 24 \mathrm{~B}$ & 109.4 \\
\hline $\mathrm{H} 24 \mathrm{~A}-\mathrm{C} 24-\mathrm{H} 24 \mathrm{~B}$ & 108.0 \\
\hline $\mathrm{C} 22-\mathrm{O} 22-\mathrm{Tb} 1$ & $130.93(12)$ \\
\hline $\mathrm{C} 27-\mathrm{O} 22-\mathrm{Tb} 1$ & $130.6(10)$ \\
\hline $\mathrm{C} 22-\mathrm{O} 22-\mathrm{H} 22 \mathrm{O}$ & $107.2(19)$ \\
\hline $\mathrm{C} 27-\mathrm{O} 22-\mathrm{H} 22 \mathrm{O}$ & $109(2)$ \\
\hline $\mathrm{Tb} 1-\mathrm{O} 22-\mathrm{H} 22 \mathrm{O}$ & $119.6(19)$ \\
\hline $\mathrm{C} 23-\mathrm{O} 23-\mathrm{Tb} 1$ & $128.64(12)$ \\
\hline $\mathrm{C} 28-\mathrm{O} 23-\mathrm{Tb} 1$ & $130.5(9)$ \\
\hline $\mathrm{C} 23-\mathrm{O} 23-\mathrm{H} 23 \mathrm{O}$ & $105.3(19)$ \\
\hline $\mathrm{C} 28-\mathrm{O} 23-\mathrm{H} 23 \mathrm{O}$ & $107(2)$ \\
\hline $\mathrm{Tb} 1-\mathrm{O} 23-\mathrm{H} 23 \mathrm{O}$ & $122.2(19)$ \\
\hline $\mathrm{C} 24-\mathrm{O} 24-\mathrm{Tb} 1$ & $126.61(12)$ \\
\hline $\mathrm{C} 29-\mathrm{O} 24-\mathrm{Tb} 1$ & $133.5(12)$ \\
\hline $\mathrm{C} 24-\mathrm{O} 24-\mathrm{H} 24 \mathrm{O}$ & $108(2)$ \\
\hline $\mathrm{C} 29-\mathrm{O} 24-\mathrm{H} 24 \mathrm{O}$ & $108(2)$ \\
\hline $\mathrm{Tb} 1-\mathrm{O} 24-\mathrm{H} 24 \mathrm{O}$ & $118(2)$ \\
\hline $\mathrm{C} 26-\mathrm{C} 25-\mathrm{C} 21$ & $116.65(16)$ \\
\hline $\mathrm{C} 26-\mathrm{C} 25-\mathrm{H} 25 \mathrm{~A}$ & 108.1 \\
\hline $\mathrm{C} 21-\mathrm{C} 25-\mathrm{H} 25 \mathrm{~A}$ & 108.1 \\
\hline $\mathrm{C} 26-\mathrm{C} 25-\mathrm{H} 25 \mathrm{~B}$ & 108.1 \\
\hline $\mathrm{C} 21-\mathrm{C} 25-\mathrm{H} 25 \mathrm{~B}$ & 108.1 \\
\hline $\mathrm{H} 25 \mathrm{~A}-\mathrm{C} 25-\mathrm{H} 25 \mathrm{~B}$ & 107.3 \\
\hline $\mathrm{C} 25-\mathrm{C} 26-\mathrm{H} 26 \mathrm{~A}$ & 109.5 \\
\hline $\mathrm{C} 25-\mathrm{C} 26-\mathrm{H} 26 \mathrm{~B}$ & 109.5 \\
\hline $\mathrm{H} 26 \mathrm{~A}-\mathrm{C} 26-\mathrm{H} 26 \mathrm{~B}$ & 109.5 \\
\hline $\mathrm{C} 25-\mathrm{C} 26-\mathrm{H} 26 \mathrm{C}$ & 109.5 \\
\hline $\mathrm{H} 26 \mathrm{~A}-\mathrm{C} 26-\mathrm{H} 26 \mathrm{C}$ & 109.5 \\
\hline $\mathrm{H} 26 \mathrm{~B}-\mathrm{C} 26-\mathrm{H} 26 \mathrm{C}$ & 109.5 \\
\hline $\mathrm{O} 22-\mathrm{C} 27-\mathrm{C} 21$ & $111.7(16)$ \\
\hline $\mathrm{O} 22-\mathrm{C} 27-\mathrm{H} 27 \mathrm{~A}$ & 109.3 \\
\hline $\mathrm{C} 21-\mathrm{C} 27-\mathrm{H} 27 \mathrm{~A}$ & 109.3 \\
\hline $\mathrm{O} 22-\mathrm{C} 27-\mathrm{H} 27 \mathrm{~B}$ & 109.3 \\
\hline $\mathrm{C} 21-\mathrm{C} 27-\mathrm{H} 27 \mathrm{~B}$ & 109.3 \\
\hline $\mathrm{H} 27 \mathrm{~A}-\mathrm{C} 27-\mathrm{H} 27 \mathrm{~B}$ & 107.9 \\
\hline $\mathrm{O} 23-\mathrm{C} 28-\mathrm{C} 21$ & $104.6(15)$ \\
\hline $\mathrm{O} 23-\mathrm{C} 28-\mathrm{H} 28 \mathrm{~A}$ & 110.8 \\
\hline $\mathrm{C} 21-\mathrm{C} 28-\mathrm{H} 28 \mathrm{~A}$ & 110.8 \\
\hline $\mathrm{O} 23-\mathrm{C} 28-\mathrm{H} 28 \mathrm{~B}$ & 110.8 \\
\hline $\mathrm{C} 21-\mathrm{C} 28-\mathrm{H} 28 \mathrm{~B}$ & 110.8 \\
\hline $\mathrm{H} 28 \mathrm{~A}-\mathrm{C} 28-\mathrm{H} 28 \mathrm{~B}$ & 108.9 \\
\hline $\mathrm{O} 24-\mathrm{C} 29-\mathrm{C} 21$ & $106.4(19)$ \\
\hline $\mathrm{O} 24-\mathrm{C} 29-\mathrm{H} 29 \mathrm{~A}$ & 110.5 \\
\hline $\mathrm{C} 21-\mathrm{C} 29-\mathrm{H} 29 \mathrm{~A}$ & 110.5 \\
\hline $\mathrm{O} 24-\mathrm{C} 29-\mathrm{H} 29 \mathrm{~B}$ & 110.5 \\
\hline $\mathrm{C} 21-\mathrm{C} 29-\mathrm{H} 29 \mathrm{~B}$ & 110.5 \\
\hline
\end{tabular}




\begin{tabular}{|c|c|c|c|}
\hline $\mathrm{Tb} 1-\mathrm{O} 13-\mathrm{H} 13 \mathrm{O}$ & $113.5(19)$ & $\mathrm{H} 29 \mathrm{~A}-\mathrm{C} 29-\mathrm{H} 29 \mathrm{~B}$ & 108.6 \\
\hline $\mathrm{O} 14-\mathrm{C} 14-\mathrm{C} 11$ & $110.51(15)$ & $\mathrm{O} 6-\mathrm{N} 2-\mathrm{O} 5$ & $123.36(17)$ \\
\hline $\mathrm{O} 14-\mathrm{C} 14-\mathrm{H} 14 \mathrm{~A}$ & 109.5 & $\mathrm{O} 6-\mathrm{N} 2-\mathrm{O} 4$ & $121.15(16)$ \\
\hline $\mathrm{C} 11-\mathrm{C} 14-\mathrm{H} 14 \mathrm{~A}$ & 109.5 & $\mathrm{O} 5-\mathrm{N} 2-\mathrm{O} 4$ & $115.50(15)$ \\
\hline $\mathrm{O} 14-\mathrm{C} 14-\mathrm{H} 14 \mathrm{~B}$ & 109.5 & $\mathrm{~N} 2-\mathrm{O} 4-\mathrm{Tb} 1$ & $98.93(10)$ \\
\hline $\mathrm{C} 11-\mathrm{C} 14-\mathrm{H} 14 \mathrm{~B}$ & 109.5 & $\mathrm{~N} 2-\mathrm{O} 5-\mathrm{Tb} 1$ & $95.35(10)$ \\
\hline $\mathrm{H} 14 \mathrm{~A}-\mathrm{C} 14-\mathrm{H} 14 \mathrm{~B}$ & 108.1 & $\mathrm{O} 3-\mathrm{N} 1-\mathrm{O} 2$ & $122.66(16)$ \\
\hline $\mathrm{C} 14-\mathrm{O} 14-\mathrm{Tb} 1$ & $131.34(11)$ & $\mathrm{O} 3-\mathrm{N} 1-\mathrm{O} 1$ & $122.51(16)$ \\
\hline $\mathrm{C} 14-\mathrm{O} 14-\mathrm{H} 14 \mathrm{O}$ & $103.8(19)$ & $\mathrm{O} 2-\mathrm{N} 1-\mathrm{O} 1$ & $114.82(15)$ \\
\hline $\mathrm{Tb} 1-\mathrm{O} 14-\mathrm{H} 14 \mathrm{O}$ & $117(2)$ & $\mathrm{N} 1-\mathrm{O} 1-\mathrm{Tb} 1$ & $97.15(10)$ \\
\hline $\mathrm{C} 16-\mathrm{C} 15-\mathrm{C} 11$ & $116.62(16)$ & $\mathrm{N} 1-\mathrm{O} 2-\mathrm{Tb} 1$ & $98.53(10)$ \\
\hline $\mathrm{C} 16-\mathrm{C} 15-\mathrm{H} 15 \mathrm{~A}$ & 108.1 & $\mathrm{O} 7-\mathrm{N} 3-\mathrm{O} 8$ & $120.91(16)$ \\
\hline $\mathrm{C} 11-\mathrm{C} 15-\mathrm{H} 15 \mathrm{~A}$ & 108.1 & $\mathrm{O} 7-\mathrm{N} 3-\mathrm{O} 9$ & $119.83(16)$ \\
\hline $\mathrm{C} 16-\mathrm{C} 15-\mathrm{H} 15 \mathrm{~B}$ & 108.1 & $\mathrm{O} 8-\mathrm{N} 3-\mathrm{O} 9$ & $119.26(16)$ \\
\hline $\mathrm{C} 11-\mathrm{C} 15-\mathrm{H} 15 \mathrm{~B}$ & 108.1 & $\mathrm{O} 32-\mathrm{C} 31-\mathrm{C} 31^{\mathrm{i}}$ & $111.02(16)$ \\
\hline $\mathrm{H} 15 \mathrm{~A}-\mathrm{C} 15-\mathrm{H} 15 \mathrm{~B}$ & 107.3 & $\mathrm{O} 32-\mathrm{C} 31-\mathrm{H} 31 \mathrm{~A}$ & 109.4 \\
\hline $\mathrm{C} 15-\mathrm{C} 16-\mathrm{H} 16 \mathrm{~A}$ & 109.5 & $\mathrm{C} 31^{\mathrm{i}}-\mathrm{C} 31-\mathrm{H} 31 \mathrm{~A}$ & 109.4 \\
\hline $\mathrm{C} 15-\mathrm{C} 16-\mathrm{H} 16 \mathrm{~B}$ & 109.5 & $\mathrm{O} 32-\mathrm{C} 31-\mathrm{H} 31 \mathrm{~B}$ & 109.4 \\
\hline $\mathrm{H} 16 \mathrm{~A}-\mathrm{C} 16-\mathrm{H} 16 \mathrm{~B}$ & 109.5 & 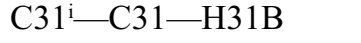 & 109.4 \\
\hline $\mathrm{C} 15-\mathrm{C} 16-\mathrm{H} 16 \mathrm{C}$ & 109.5 & $\mathrm{H} 31 \mathrm{~A}-\mathrm{C} 31-\mathrm{H} 31 \mathrm{~B}$ & 108.0 \\
\hline $\mathrm{H} 16 \mathrm{~A}-\mathrm{C} 16-\mathrm{H} 16 \mathrm{C}$ & 109.5 & $\mathrm{C} 31-\mathrm{O} 32-\mathrm{C} 33$ & $110.89(17)$ \\
\hline $\mathrm{H} 16 \mathrm{~B}-\mathrm{C} 16-\mathrm{H} 16 \mathrm{C}$ & 109.5 & $\mathrm{O} 32-\mathrm{C} 33-\mathrm{H} 33 \mathrm{~A}$ & 109.5 \\
\hline $\mathrm{C} 23-\mathrm{C} 21-\mathrm{C} 24$ & $110.75(17)$ & $\mathrm{O} 32-\mathrm{C} 33-\mathrm{H} 33 \mathrm{~B}$ & 109.5 \\
\hline $\mathrm{C} 23-\mathrm{C} 21-\mathrm{C} 22$ & $111.65(17)$ & $\mathrm{H} 33 \mathrm{~A}-\mathrm{C} 33-\mathrm{H} 33 \mathrm{~B}$ & 109.5 \\
\hline $\mathrm{C} 24-\mathrm{C} 21-\mathrm{C} 22$ & $110.43(17)$ & $\mathrm{O} 32-\mathrm{C} 33-\mathrm{H} 33 \mathrm{C}$ & 109.5 \\
\hline $\mathrm{C} 27-\mathrm{C} 21-\mathrm{C} 29$ & $115.7(16)$ & $\mathrm{H} 33 \mathrm{~A}-\mathrm{C} 33-\mathrm{H} 33 \mathrm{C}$ & 109.5 \\
\hline $\mathrm{C} 27-\mathrm{C} 21-\mathrm{C} 25$ & $106.3(9)$ & $\mathrm{H} 33 \mathrm{~B}-\mathrm{C} 33-\mathrm{H} 33 \mathrm{C}$ & 109.5 \\
\hline $\mathrm{C} 23-\mathrm{C} 21-\mathrm{C} 25$ & $108.92(15)$ & & \\
\hline $\mathrm{C} 14-\mathrm{C} 11-\mathrm{C} 12-\mathrm{O} 12$ & $-68.7(2)$ & $\mathrm{C} 27-\mathrm{C} 21-\mathrm{C} 25-\mathrm{C} 26$ & $77.9(14)$ \\
\hline $\mathrm{C} 13-\mathrm{C} 11-\mathrm{C} 12-\mathrm{O} 12$ & $57.4(2)$ & $\mathrm{C} 23-\mathrm{C} 21-\mathrm{C} 25-\mathrm{C} 26$ & $-69.4(2)$ \\
\hline $\mathrm{C} 15-\mathrm{C} 11-\mathrm{C} 12-\mathrm{O} 12$ & $172.01(15)$ & $\mathrm{C} 24-\mathrm{C} 21-\mathrm{C} 25-\mathrm{C} 26$ & $171.49(18)$ \\
\hline $\mathrm{C} 11-\mathrm{C} 12-\mathrm{O} 12-\mathrm{Tb} 1$ & $10.5(2)$ & $\mathrm{C} 22-\mathrm{C} 21-\mathrm{C} 25-\mathrm{C} 26$ & $52.7(2)$ \\
\hline $\mathrm{C} 14-\mathrm{C} 11-\mathrm{C} 13-\mathrm{O} 13$ & $73.16(19)$ & $\mathrm{C} 29-\mathrm{C} 21-\mathrm{C} 25-\mathrm{C} 26$ & $-160.8(16)$ \\
\hline $\mathrm{C} 12-\mathrm{C} 11-\mathrm{C} 13-\mathrm{O} 13$ & $-53.5(2)$ & $\mathrm{C} 28-\mathrm{C} 21-\mathrm{C} 25-\mathrm{C} 26$ & $-43.9(12)$ \\
\hline $\mathrm{C} 15-\mathrm{C} 11-\mathrm{C} 13-\mathrm{O} 13$ & $-170.58(15)$ & $\mathrm{Tb} 1-\mathrm{O} 22-\mathrm{C} 27-\mathrm{C} 21$ & $-27(3)$ \\
\hline $\mathrm{C} 11-\mathrm{C} 13-\mathrm{O} 13-\mathrm{Tb} 1$ & $-18.1(2)$ & $\mathrm{C} 29-\mathrm{C} 21-\mathrm{C} 27-\mathrm{O} 22$ & $78(2)$ \\
\hline $\mathrm{C} 12-\mathrm{C} 11-\mathrm{C} 14-\mathrm{O} 14$ & $76.17(19)$ & $\mathrm{C} 25-\mathrm{C} 21-\mathrm{C} 27-\mathrm{O} 22$ & $-170.9(15)$ \\
\hline $\mathrm{C} 13-\mathrm{C} 11-\mathrm{C} 14-\mathrm{O} 14$ & $-50.5(2)$ & $\mathrm{C} 28-\mathrm{C} 21-\mathrm{C} 27-\mathrm{O} 22$ & $-54(2)$ \\
\hline $\mathrm{C} 15-\mathrm{C} 11-\mathrm{C} 14-\mathrm{O} 14$ & $-164.36(15)$ & $\mathrm{Tb} 1-\mathrm{O} 23-\mathrm{C} 28-\mathrm{C} 21$ & $-29(2)$ \\
\hline $\mathrm{C} 11-\mathrm{C} 14-\mathrm{O} 14-\mathrm{Tb} 1$ & $-25.1(2)$ & $\mathrm{C} 27-\mathrm{C} 21-\mathrm{C} 28-\mathrm{O} 23$ & 78.9 (19) \\
\hline $\mathrm{C} 14-\mathrm{C} 11-\mathrm{C} 15-\mathrm{C} 16$ & $-57.1(2)$ & $\mathrm{C} 29-\mathrm{C} 21-\mathrm{C} 28-\mathrm{O} 23$ & $-54.7(19)$ \\
\hline $\mathrm{C} 12-\mathrm{C} 11-\mathrm{C} 15-\mathrm{C} 16$ & $64.8(2)$ & $\mathrm{C} 25-\mathrm{C} 21-\mathrm{C} 28-\mathrm{O} 23$ & $-164.4(12)$ \\
\hline $\mathrm{C} 13-\mathrm{C} 11-\mathrm{C} 15-\mathrm{C} 16$ & $-175.52(17)$ & $\mathrm{Tb} 1-\mathrm{O} 24-\mathrm{C} 29-\mathrm{C} 21$ & $-21(3)$ \\
\hline $\mathrm{C} 23-\mathrm{C} 21-\mathrm{C} 22-\mathrm{O} 22$ & $-80.2(2)$ & $\mathrm{C} 27-\mathrm{C} 21-\mathrm{C} 29-\mathrm{O} 24$ & $-52(2)$ \\
\hline $\mathrm{C} 24-\mathrm{C} 21-\mathrm{C} 22-\mathrm{O} 22$ & $43.5(2)$ & $\mathrm{C} 25-\mathrm{C} 21-\mathrm{C} 29-\mathrm{O} 24$ & $-166.2(17)$ \\
\hline $\mathrm{C} 25-\mathrm{C} 21-\mathrm{C} 22-\mathrm{O} 22$ & $159.38(18)$ & $\mathrm{C} 28-\mathrm{C} 21-\mathrm{C} 29-\mathrm{O} 24$ & $81(2)$ \\
\hline $\mathrm{C} 24-\mathrm{C} 21-\mathrm{C} 23-\mathrm{O} 23$ & $-75.7(2)$ & $\mathrm{O} 6-\mathrm{N} 2-\mathrm{O} 4-\mathrm{Tb} 1$ & $-177.24(14)$ \\
\hline
\end{tabular}




$\begin{array}{llll}\mathrm{C} 22-\mathrm{C} 21-\mathrm{C} 23-\mathrm{O} 23 & 47.8(2) & \mathrm{O} 5-\mathrm{N} 2-\mathrm{O} 4-\mathrm{Tb} 1 & 3.28(16) \\ \mathrm{C} 25-\mathrm{C} 21-\mathrm{C} 23-\mathrm{O} 23 & 168.37(19) & \mathrm{O} 6-\mathrm{N} 2-\mathrm{O} 5-\mathrm{Tb} 1 & 177.39(15) \\ \mathrm{C} 23-\mathrm{C} 21-\mathrm{C} 24-\mathrm{O} 24 & 42.0(2) & \mathrm{O} 4-\mathrm{N} 2-\mathrm{O} 5-\mathrm{Tb} 1 & -3.14(15) \\ \mathrm{C} 22-\mathrm{C} 21-\mathrm{C} 24-\mathrm{O} 24 & -82.2(2) & \mathrm{O} 3-\mathrm{N} 1-\mathrm{O} 1-\mathrm{Tb} 1 & 179.72(15) \\ \mathrm{C} 25-\mathrm{C} 21-\mathrm{C} 24-\mathrm{O} 24 & 159.84(18) & \mathrm{O} 2-\mathrm{N} 1-\mathrm{O} 1-\mathrm{Tb} 1 & 0.20(15) \\ \mathrm{C} 21-\mathrm{C} 22-\mathrm{O} 22-\mathrm{Tb} 1 & 32.0(3) & \mathrm{O} 3-\mathrm{N} 1-\mathrm{O} 2-\mathrm{Tb} 1 & -179.72(15) \\ \mathrm{C} 21-\mathrm{C} 23-\mathrm{O} 23-\mathrm{Tb} 1 & 26.9(3) & \mathrm{O} 1-\mathrm{N} 1-\mathrm{O} 2-\mathrm{Tb} 1 & -0.21(15) \\ \mathrm{C} 21-\mathrm{C} 24-\mathrm{O} 24-\mathrm{Tb} 1 & 42.4(3) & \mathrm{C} 31-\mathrm{C} 31-\mathrm{O} 32-\mathrm{C} 33 & -174.3(2)\end{array}$

Symmetry code: (i) $-x+1 / 2, y,-z+1$.

Hydrogen-bond geometry $\left(\AA,{ }^{\circ}\right)$

\begin{tabular}{lllll}
\hline$D-\mathrm{H} \cdots A$ & $D-\mathrm{H}$ & $\mathrm{H} \cdots A$ & $D \cdots A$ & $D-\mathrm{H}^{\cdots} A$ \\
\hline $\mathrm{O} 12-\mathrm{H} 12 O \cdots \mathrm{O} 9^{\mathrm{ii}}$ & $0.72(2)$ & $1.98(2)$ & $2.683(2)$ & $167(3)$ \\
$\mathrm{O} 13-\mathrm{H} 13 O \cdots \mathrm{O} 32$ & $0.74(2)$ & $2.04(2)$ & $2.774(2)$ & $170(3)$ \\
$\mathrm{O} 14-\mathrm{H} 14 O \cdots \mathrm{O} 2^{\mathrm{iii}}$ & $0.74(2)$ & $2.07(3)$ & $2.7935(19)$ & $165(3)$ \\
$\mathrm{O} 22-\mathrm{H} 22 O \cdots \mathrm{O} 8$ & $0.73(2)$ & $2.01(3)$ & $2.735(2)$ & $172(3)$ \\
$\mathrm{O} 23-\mathrm{H} 23 O \cdots \mathrm{O} 4^{\mathrm{iii}}$ & $0.69(2)$ & $2.16(2)$ & $2.8550(19)$ & $175(2)$ \\
$\mathrm{O} 24-\mathrm{H} 24 O \cdots{ }^{\text {iv }}$ & $0.74(3)$ & $1.93(3)$ & $2.6624(19)$ & $171(3)$ \\
$\mathrm{C} 22-\mathrm{H} 22 B \cdots 3^{v}$ & 0.99 & 2.44 & $3.358(3)$ & 153 \\
$\mathrm{C} 24-\mathrm{H} 24 B \cdots \mathrm{O} 7^{\mathrm{vi}}$ & 0.99 & 2.49 & $3.220(3)$ & 130 \\
$\mathrm{C} 29-\mathrm{H} 29 A \cdots \mathrm{O} 7^{\mathrm{vi}}$ & 0.99 & 2.41 & $3.27(3)$ & 146
\end{tabular}

Symmetry codes: (ii) $x+1 / 2,-y+1, z$; (iii) $-x+1, y-1 / 2,-z+3 / 2$; (iv) $-x+1, y+1 / 2,-z+3 / 2$; (v) $x-1 / 2,-y+1, z$; (vi) $-x+1 / 2,-y+3 / 2,-z+3 / 2$.

(Compound-2) Aquanitratobis[1,1,1-tris(hydroxymethyl)propane]terbium(III) dinitrate

Crystal data

$\left[\mathrm{Tb}\left(\mathrm{NO}_{3}\right)\left(\mathrm{C}_{6} \mathrm{H}_{14} \mathrm{O}_{3}\right)_{2}\left(\mathrm{H}_{2} \mathrm{O}\right)\right]\left(\mathrm{NO}_{3}\right)_{2}$

$M_{r}=631.31$

Monoclinic, $P 2{ }_{1} / c$

$a=9.1440(6) \AA$

$b=12.7870(7) \AA$

$c=19.7151(12) \AA$

$\beta=101.796(2)^{\circ}$

$V=2256.5(2) \AA^{3}$

$Z=4$

\section{Data collection}

Bruker D8 VENTURE/PHOTON100 CMOS diffractometer

Radiation source: fine-focus sealed tube Graphite monochromator Detector resolution: 10.4167 pixels $\mathrm{mm}^{-1}$ $\varphi$ and $\omega$ scans Absorption correction: multi-scan

(SADABS; Bruker, 2014)

$T_{\min }=0.636, T_{\max }=0.746$
$F(000)=1264$

$D_{\mathrm{x}}=1.858 \mathrm{Mg} \mathrm{m}^{-3}$

Mo $K \alpha$ radiation, $\lambda=0.71073 \AA$

Cell parameters from 9581 reflections

$\theta=3.1-28.3^{\circ}$

$\mu=3.22 \mathrm{~mm}^{-1}$

$T=100 \mathrm{~K}$

Block, colourless

$0.36 \times 0.19 \times 0.18 \mathrm{~mm}$

244328 measured reflections 5629 independent reflections 5542 reflections with $I>2 \sigma(I)$

$R_{\text {int }}=0.023$

$\theta_{\text {max }}=28.4^{\circ}, \theta_{\text {min }}=3.6^{\circ}$

$h=-12 \rightarrow 12$

$k=-17 \rightarrow 17$

$l=-26 \rightarrow 26$ 


\section{Refinement}

Refinement on $F^{2}$

Least-squares matrix: full

$R\left[F^{2}>2 \sigma\left(F^{2}\right)\right]=0.012$

$w R\left(F^{2}\right)=0.029$

$S=1.13$

5629 reflections

326 parameters

0 restraints
Primary atom site location: structure-invariant direct methods

Hydrogen site location: mixed

$\mathrm{H}$ atoms treated by a mixture of independent and constrained refinement

$w=1 /\left[\sigma^{2}\left(F_{\mathrm{o}}^{2}\right)+(0.0128 P)^{2}+1.457 P\right]$ where $P=\left(F_{\mathrm{o}}{ }^{2}+2 F_{\mathrm{c}}{ }^{2}\right) / 3$

$(\Delta / \sigma)_{\max }=0.001$

$\Delta \rho_{\max }=0.74 \mathrm{e} \AA^{-3}$

$\Delta \rho_{\min }=-0.26$ e $\AA^{-3}$

Special details

Geometry. All esds (except the esd in the dihedral angle between two 1.s. planes) are estimated using the full covariance matrix. The cell esds are taken into account individually in the estimation of esds in distances, angles and torsion angles; correlations between esds in cell parameters are only used when they are defined by crystal symmetry. An approximate (isotropic) treatment of cell esds is used for estimating esds involving l.s. planes.

Fractional atomic coordinates and isotropic or equivalent isotropic displacement parameters $\left(\AA^{2}\right)$

\begin{tabular}{|c|c|c|c|c|c|}
\hline & $x$ & $y$ & $z$ & $U_{\text {iso }} * / U_{\text {eq }}$ & Occ. $(<1)$ \\
\hline Tb1 & $0.15357(2)$ & $0.39026(2)$ & $0.37356(2)$ & $0.00991(2)$ & \\
\hline $\mathrm{C} 11$ & $0.20317(14)$ & $0.11240(9)$ & $0.41042(7)$ & $0.0134(2)$ & \\
\hline $\mathrm{C} 12$ & $0.05513(15)$ & $0.14541(10)$ & $0.42837(7)$ & $0.0170(2)$ & \\
\hline $\mathrm{H} 12 \mathrm{~A}$ & -0.0282 & 0.1120 & 0.3955 & $0.020^{*}$ & \\
\hline H12B & 0.0516 & 0.1206 & 0.4756 & $0.020^{*}$ & \\
\hline $\mathrm{O} 12$ & $0.03581(10)$ & $0.25678(7)$ & $0.42542(5)$ & $0.01517(17)$ & \\
\hline $\mathrm{C} 13$ & $0.19968(16)$ & $0.12622(10)$ & $0.33317(7)$ & $0.0168(2)$ & \\
\hline H13A & 0.3014 & 0.1158 & 0.3243 & $0.020^{*}$ & \\
\hline H13B & 0.1335 & 0.0726 & 0.3067 & $0.020^{*}$ & \\
\hline $\mathrm{O} 13$ & $0.14671(11)$ & $0.22883(7)$ & $0.30972(5)$ & $0.01632(18)$ & \\
\hline $\mathrm{C} 14$ & $0.33441(14)$ & $0.17092(10)$ & $0.45474(7)$ & $0.0159(2)$ & \\
\hline H14A & 0.3238 & 0.1703 & 0.5037 & $0.019^{*}$ & \\
\hline H14B & 0.4288 & 0.1347 & 0.4521 & $0.019^{*}$ & \\
\hline $\mathrm{O} 14$ & $0.34140(11)$ & $0.27755(7)$ & $0.43195(5)$ & $0.01548(18)$ & \\
\hline $\mathrm{C} 15$ & $0.22392(16)$ & $-0.00526(10)$ & $0.42866(7)$ & $0.0191(3)$ & \\
\hline $\mathrm{H} 15 \mathrm{~A}$ & 0.2419 & -0.0124 & 0.4797 & $0.023^{*}$ & $0.827(4)$ \\
\hline H15B & 0.1291 & -0.0418 & 0.4093 & $0.023^{*}$ & $0.827(4)$ \\
\hline $\mathrm{H} 15 \mathrm{C}$ & 0.2488 & -0.0122 & 0.4797 & $0.023^{*}$ & $0.173(4)$ \\
\hline H15D & 0.3105 & -0.0315 & 0.4106 & $0.023^{*}$ & $0.173(4)$ \\
\hline $\mathrm{C} 16$ & $0.3507(2)$ & $-0.06169(13)$ & $0.40298(9)$ & $0.0230(4)$ & $0.827(4)$ \\
\hline H16A & 0.3537 & -0.1352 & 0.4173 & $0.034^{*}$ & $0.827(4)$ \\
\hline H16B & 0.3331 & -0.0577 & 0.3523 & $0.034^{*}$ & $0.827(4)$ \\
\hline $\mathrm{H} 16 \mathrm{C}$ & 0.4462 & -0.0282 & 0.4229 & $0.034^{*}$ & $0.827(4)$ \\
\hline $\mathrm{C} 17$ & $0.0871(9)$ & $-0.0763(6)$ & $0.4002(4)$ & $0.0184(19)^{*}$ & $0.173(4)$ \\
\hline H17A & 0.1111 & -0.1488 & 0.4144 & $0.028^{*}$ & $0.173(4)$ \\
\hline H17B & 0.0011 & -0.0528 & 0.4188 & $0.028^{*}$ & $0.173(4)$ \\
\hline $\mathrm{H} 17 \mathrm{C}$ & 0.0629 & -0.0722 & 0.3495 & $0.028^{*}$ & $0.173(4)$ \\
\hline $\mathrm{C} 21$ & $0.36977(14)$ & $0.59444(10)$ & $0.30982(7)$ & $0.0141(2)$ & \\
\hline $\mathrm{C} 22$ & $0.32638(15)$ & $0.51321(10)$ & $0.25283(6)$ & $0.0157(2)$ & \\
\hline
\end{tabular}




\begin{tabular}{|c|c|c|c|c|}
\hline $\mathrm{H} 22 \mathrm{~A}$ & 0.2465 & 0.5419 & 0.2159 & $0.019 *$ \\
\hline $\mathrm{H} 22 \mathrm{~B}$ & 0.4139 & 0.4975 & 0.2321 & $0.019 *$ \\
\hline $\mathrm{O} 22$ & $0.27453(11)$ & $0.41792(7)$ & $0.27942(5)$ & $0.01562(17)$ \\
\hline $\mathrm{C} 23$ & $0.46779(14)$ & $0.54531(10)$ & $0.37450(7)$ & $0.0158(2)$ \\
\hline $\mathrm{H} 23 \mathrm{~A}$ & 0.5405 & 0.4972 & 0.3600 & $0.019 *$ \\
\hline $\mathrm{H} 23 \mathrm{~B}$ & 0.5249 & 0.6013 & 0.4030 & $0.019 *$ \\
\hline $\mathrm{O} 23$ & $0.38207(10)$ & $0.48831(7)$ & $0.41624(5)$ & $0.01434(17)$ \\
\hline $\mathrm{C} 24$ & $0.23305(14)$ & $0.64798(10)$ & $0.32772(7)$ & $0.0157(2)$ \\
\hline $\mathrm{H} 24 \mathrm{~A}$ & 0.2650 & 0.6928 & 0.3690 & $0.019 *$ \\
\hline $\mathrm{H} 24 \mathrm{~B}$ & 0.1856 & 0.6933 & 0.2887 & $0.019 *$ \\
\hline $\mathrm{O} 24$ & $0.12570(11)$ & $0.57223(7)$ & $0.34145(5)$ & $0.01533(17)$ \\
\hline $\mathrm{C} 25$ & $0.46674(15)$ & $0.67891(11)$ & $0.28378(7)$ & $0.0194(3)$ \\
\hline $\mathrm{H} 25 \mathrm{~A}$ & 0.4749 & 0.7398 & 0.3154 & $0.023^{*}$ \\
\hline $\mathrm{H} 25 \mathrm{~B}$ & 0.5686 & 0.6503 & 0.2872 & $0.023^{*}$ \\
\hline $\mathrm{C} 26$ & $0.41016(18)$ & $0.71744(12)$ & $0.20979(8)$ & $0.0256(3)$ \\
\hline H26A & 0.4789 & 0.7703 & 0.1984 & $0.038 *$ \\
\hline H26B & 0.4046 & 0.6585 & 0.1776 & $0.038^{*}$ \\
\hline $\mathrm{H} 26 \mathrm{C}$ & 0.3106 & 0.7482 & 0.2058 & $0.038 *$ \\
\hline N1 & $-0.15472(12)$ & $0.43478(8)$ & $0.30929(6)$ & $0.0147(2)$ \\
\hline $\mathrm{O} 1$ & $-0.06405(11)$ & $0.39309(7)$ & $0.27587(5)$ & $0.01717(18)$ \\
\hline $\mathrm{O} 2$ & $-0.10340(10)$ & $0.45124(7)$ & $0.37367(5)$ & $0.01666(18)$ \\
\hline $\mathrm{O} 3$ & $-0.28209(11)$ & $0.45781(8)$ & $0.28147(5)$ & $0.0226(2)$ \\
\hline N2 & $0.72651(12)$ & $0.29286(8)$ & $0.48389(5)$ & 0.01374 (19) \\
\hline $\mathrm{O} 4$ & 0.70888 (11) & $0.20729(8)$ & $0.45553(5)$ & $0.0224(2)$ \\
\hline $\mathrm{O} 5$ & $0.85643(10)$ & $0.32966(7)$ & $0.50584(5)$ & $0.01657(18)$ \\
\hline O6 & $0.61580(10)$ & $0.34701(8)$ & $0.49253(5)$ & $0.0213(2)$ \\
\hline N3 & $0.18037(13)$ & $0.24790(9)$ & $0.13412(6)$ & $0.0163(2)$ \\
\hline $\mathrm{O} 7$ & 0.19294 (13) & $0.21012(8)$ & $0.07818(5)$ & $0.0253(2)$ \\
\hline $\mathrm{O} 8$ & 0.10941 (12) & $0.19955(8)$ & $0.17319(5)$ & $0.0226(2)$ \\
\hline O9 & $0.24079(15)$ & $0.33293(9)$ & $0.15397(6)$ & 0.0319 \\
\hline O10 & $0.15368(11)$ & $0.45418(8)$ & $0.48688(5)$ & $0.01625(18)$ \\
\hline $\mathrm{H} 1 \mathrm{OA}$ & $0.160(2)$ & $0.4204(17)$ & $0.5185(11)$ & $0.032(5)^{*}$ \\
\hline $\mathrm{H} 1 \mathrm{OB}$ & $0.148(2)$ & $0.5141(18)$ & $0.4948(11)$ & $0.036(6)^{*}$ \\
\hline $\mathrm{H} 12 \mathrm{O}$ & $-0.017(2)$ & $0.2727(15)$ & $0.4478(10)$ & $0.028(5)^{*}$ \\
\hline $\mathrm{H} 13 \mathrm{O}$ & $0.131(2)$ & $0.2279(15)$ & $0.2698(11)$ & $0.027(5)^{*}$ \\
\hline $\mathrm{H} 14 \mathrm{O}$ & $0.416(2)$ & $0.2983(16)$ & $0.4460(10)$ & $0.030(5)^{*}$ \\
\hline $\mathrm{H} 22 \mathrm{O}$ & $0.255(2)$ & $0.3813(16)$ & $0.2486(12)$ & $0.034(6)^{*}$ \\
\hline $\mathrm{H} 23 \mathrm{O}$ & $0.371(2)$ & $0.5220(16)$ & $0.4430(10)$ & $0.026(5)^{*}$ \\
\hline $\mathrm{H} 24 \mathrm{O}$ & $0.058(2)$ & $0.6003(15)$ & $0.3462(10)$ & $0.023(5)^{*}$ \\
\hline
\end{tabular}

Atomic displacement parameters $\left(\AA^{2}\right)$

\begin{tabular}{lllllll}
\hline & $U^{11}$ & $U^{22}$ & $U^{33}$ & $U^{12}$ & $U^{13}$ & $U^{23}$ \\
\hline Tb1 & $0.01123(3)$ & $0.00934(3)$ & $0.00935(3)$ & $0.00074(2)$ & $0.00253(2)$ & $-0.00031(2)$ \\
$\mathrm{C} 11$ & $0.0172(6)$ & $0.0099(5)$ & $0.0137(6)$ & $0.0001(4)$ & $0.0042(4)$ & $-0.0001(4)$ \\
$\mathrm{C} 12$ & $0.0188(6)$ & $0.0110(6)$ & $0.0231(6)$ & $-0.0014(5)$ & $0.0088(5)$ & $0.0006(5)$ \\
$\mathrm{O} 12$ & $0.0168(4)$ & $0.0119(4)$ & $0.0195(4)$ & $0.0010(3)$ & $0.0102(4)$ & $-0.0010(3)$ \\
$\mathrm{C} 13$ & $0.0243(6)$ & $0.0118(5)$ & $0.0148(6)$ & $0.0030(5)$ & $0.0053(5)$ & $-0.0012(4)$
\end{tabular}




\begin{tabular}{lllllll} 
& & & & & \\
O13 & $0.0262(5)$ & $0.0123(4)$ & $0.0100(4)$ & $0.0026(4)$ & $0.0026(4)$ & $-0.0008(3)$ \\
C14 & $0.0176(6)$ & $0.0114(5)$ & $0.0175(6)$ & $0.0017(5)$ & $0.0007(5)$ & $0.0019(5)$ \\
O14 & $0.0128(4)$ & $0.0110(4)$ & $0.0206(5)$ & $-0.0008(3)$ & $-0.0014(3)$ & $0.0007(3)$ \\
C15 & $0.0251(7)$ & $0.0113(6)$ & $0.0213(6)$ & $0.0012(5)$ & $0.0052(5)$ & $0.0018(5)$ \\
C16 & $0.0315(9)$ & $0.0147(8)$ & $0.0227(8)$ & $0.0072(6)$ & $0.0054(7)$ & $0.0015(6)$ \\
C21 & $0.0153(6)$ & $0.0127(5)$ & $0.0155(6)$ & $-0.0008(4)$ & $0.0058(4)$ & $-0.0002(4)$ \\
C22 & $0.0202(6)$ & $0.0136(6)$ & $0.0146(5)$ & $-0.0023(5)$ & $0.0067(5)$ & $0.0007(4)$ \\
O22 & $0.0215(5)$ & $0.0119(4)$ & $0.0154(4)$ & $-0.0024(4)$ & $0.0082(4)$ & $-0.0030(4)$ \\
C23 & $0.0136(5)$ & $0.0176(6)$ & $0.0170(6)$ & $-0.0018(5)$ & $0.0050(4)$ & $-0.0002(5)$ \\
O23 & $0.0160(4)$ & $0.0138(4)$ & $0.0135(4)$ & $-0.0010(3)$ & $0.0039(3)$ & $-0.0010(3)$ \\
C24 & $0.0176(6)$ & $0.0111(5)$ & $0.0199(6)$ & $-0.0003(4)$ & $0.0072(5)$ & $0.0008(5)$ \\
O24 & $0.0139(4)$ & $0.0117(4)$ & $0.0223(5)$ & $0.0020(3)$ & $0.0081(4)$ & $0.0011(3)$ \\
C25 & $0.0215(6)$ & $0.0156(6)$ & $0.0235(6)$ & $-0.0038(5)$ & $0.0101(5)$ & $0.0002(5)$ \\
C26 & $0.0306(7)$ & $0.0204(7)$ & $0.0286(7)$ & $-0.0004(6)$ & $0.0126(6)$ & $0.0078(6)$ \\
N1 & $0.0141(5)$ & $0.0139(5)$ & $0.0162(5)$ & $0.0002(4)$ & $0.0036(4)$ & $0.0037(4)$ \\
O1 & $0.0157(4)$ & $0.0220(5)$ & $0.0142(4)$ & $0.0024(3)$ & $0.0037(3)$ & $-0.0023(3)$ \\
O2 & $0.0181(4)$ & $0.0202(5)$ & $0.0123(4)$ & $0.0027(4)$ & $0.0046(3)$ & $0.0013(3)$ \\
O3 & $0.0132(4)$ & $0.0289(5)$ & $0.0247(5)$ & $0.0042(4)$ & $0.0014(4)$ & $0.0064(4)$ \\
N2 & $0.0149(5)$ & $0.0149(5)$ & $0.0119(5)$ & $0.0005(4)$ & $0.0037(4)$ & $0.0002(4)$ \\
O4 & $0.0239(5)$ & $0.0153(4)$ & $0.0289(5)$ & $-0.0022(4)$ & $0.0075(4)$ & $-0.0079(4)$ \\
O5 & $0.0128(4)$ & $0.0182(4)$ & $0.0193(4)$ & $-0.0013(3)$ & $0.0046(3)$ & $-0.0026(4)$ \\
O6 & $0.0125(4)$ & $0.0218(5)$ & $0.0287(5)$ & $0.0025(4)$ & $0.0023(4)$ & $-0.0096(4)$ \\
N3 & $0.0200(5)$ & $0.0160(5)$ & $0.0130(5)$ & $-0.0023(4)$ & $0.0036(4)$ & $-0.0019(4)$ \\
O7 & $0.0388(6)$ & $0.0249(5)$ & $0.0143(4)$ & $-0.0077(4)$ & $0.0104(4)$ & $-0.0073(4)$ \\
O8 & $0.0263(5)$ & $0.0272(5)$ & $0.0158(4)$ & $-0.0126(4)$ & $0.0079(4)$ & $-0.0039(4)$ \\
O9 & $0.0526(7)$ & $0.0215(5)$ & $0.0251(5)$ & $-0.0174(5)$ & $0.0161(5)$ & $-0.0096(4)$ \\
O10 & $0.0251(5)$ & $0.0129(4)$ & $0.0114(4)$ & $0.0005(4)$ & $0.0054(4)$ & $-0.0003(4)$ \\
& & & & & \\
\hline
\end{tabular}

Geometric parameters $\left(\AA,{ }^{o}\right)$

\begin{tabular}{llll}
\hline $\mathrm{Tb} 1-\mathrm{O} 14$ & $2.3545(9)$ & $\mathrm{C} 17-\mathrm{H} 17 \mathrm{~B}$ & 0.9800 \\
$\mathrm{~Tb} 1-\mathrm{O} 12$ & $2.3597(9)$ & $\mathrm{C} 17-\mathrm{H} 17 \mathrm{C}$ & 0.9800 \\
$\mathrm{~Tb} 1-\mathrm{O} 22$ & $2.3734(9)$ & $\mathrm{C} 21-\mathrm{C} 22$ & $1.5220(17)$ \\
$\mathrm{Tb} 1-\mathrm{O} 10$ & $2.3786(9)$ & $\mathrm{C} 21-\mathrm{C} 24$ & $1.5286(17)$ \\
$\mathrm{Tb} 1-\mathrm{O} 24$ & $2.4112(9)$ & $\mathrm{C} 21-\mathrm{C} 23$ & $1.5353(18)$ \\
$\mathrm{Tb} 1-\mathrm{O} 13$ & $2.4119(9)$ & $\mathrm{C} 21-\mathrm{C} 25$ & $1.5499(17)$ \\
$\mathrm{Tb} 1-\mathrm{O} 23$ & $2.4344(9)$ & $\mathrm{C} 22-\mathrm{O} 22$ & $1.4443(15)$ \\
$\mathrm{Tb} 1-\mathrm{O} 1$ & $2.4706(10)$ & $\mathrm{C} 22-\mathrm{H} 22 \mathrm{~A}$ & 0.9900 \\
$\mathrm{~Tb} 1-\mathrm{O} 2$ & $2.4762(9)$ & $\mathrm{C} 22-\mathrm{H} 22 \mathrm{~B}$ & 0.9900 \\
$\mathrm{C} 11-\mathrm{C} 13$ & $1.5269(18)$ & $\mathrm{O} 22-\mathrm{H} 22 \mathrm{O}$ & $0.76(2)$ \\
$\mathrm{C} 11-\mathrm{C} 12$ & $1.5271(18)$ & $\mathrm{C} 23-\mathrm{O} 23$ & $1.4444(15)$ \\
$\mathrm{C} 11-\mathrm{C} 14$ & $1.5281(17)$ & $\mathrm{C} 23-\mathrm{H} 23 \mathrm{~A}$ & 0.9900 \\
$\mathrm{C} 11-\mathrm{C} 15$ & $1.5497(17)$ & $\mathrm{C} 23-\mathrm{H} 23 \mathrm{~B}$ & 0.9900 \\
$\mathrm{C} 12-\mathrm{O} 12$ & $1.4347(15)$ & $\mathrm{O} 23-\mathrm{H} 23 \mathrm{O}$ & $0.71(2)$ \\
$\mathrm{C} 12-\mathrm{H} 12 \mathrm{~A}$ & 0.9900 & $\mathrm{C} 24-\mathrm{O} 24$ & $1.4436(15)$ \\
$\mathrm{C} 12-\mathrm{H} 12 \mathrm{~B}$ & 0.9900 & $\mathrm{C} 24-\mathrm{H} 24 \mathrm{~A}$ & 0.9900 \\
$\mathrm{O} 12-\mathrm{H} 12 \mathrm{O}$ & $0.74(2)$ & $\mathrm{C} 24-\mathrm{H} 24 \mathrm{~B}$ & 0.9900 \\
$\mathrm{C} 13-\mathrm{O} 13$ & $1.4417(15)$ & $\mathrm{O} 24-\mathrm{H} 24 \mathrm{O}$ & $0.73(2)$
\end{tabular}


C13-H13A
C13-H13B
O13-H13O
C14-O14
C14-H14A
C14-H14B
O14-H14O
C15-C16
C15-C17
C15-H15A
C15-H15B
C15-H15C
C15-H15D
C16-H16A
C16-H16B
C16-H16C
C17-H17A

O14-Tb1-O12

O14-Tb1-O22

$\mathrm{O} 12-\mathrm{Tb} 1-\mathrm{O} 22$

O14-Tb1-O10

$\mathrm{O} 12-\mathrm{Tb} 1-\mathrm{O} 10$

$\mathrm{O} 22-\mathrm{Tb} 1-\mathrm{O} 10$

$\mathrm{O} 14-\mathrm{Tb} 1-\mathrm{O} 24$

$\mathrm{O} 12-\mathrm{Tb} 1-\mathrm{O} 24$

$\mathrm{O} 22-\mathrm{Tb} 1-\mathrm{O} 24$

O10- Tb1-O24

$\mathrm{O} 14-\mathrm{Tb} 1-\mathrm{O} 13$

$\mathrm{O} 12-\mathrm{Tb} 1-\mathrm{O} 13$

$\mathrm{O} 22-\mathrm{Tb} 1-\mathrm{O} 13$

$\mathrm{O} 10-\mathrm{Tb} 1-\mathrm{O} 13$

$\mathrm{O} 24-\mathrm{Tb} 1-\mathrm{O} 13$

$\mathrm{O} 14-\mathrm{Tb} 1-\mathrm{O} 23$

$\mathrm{O} 12-\mathrm{Tb} 1-\mathrm{O} 23$

$\mathrm{O} 22-\mathrm{Tb} 1-\mathrm{O} 23$

$\mathrm{O} 10-\mathrm{Tb} 1-\mathrm{O} 23$

$\mathrm{O} 24-\mathrm{Tb} 1-\mathrm{O} 23$

$\mathrm{O} 13-\mathrm{Tb} 1-\mathrm{O} 23$

O14-Tb1-O1

$\mathrm{O} 12-\mathrm{Tb} 1-\mathrm{O} 1$

$\mathrm{O} 22-\mathrm{Tb} 1-\mathrm{O} 1$

$\mathrm{O} 10-\mathrm{Tb} 1-\mathrm{O} 1$

$\mathrm{O} 24-\mathrm{Tb} 1-\mathrm{O} 1$

$\mathrm{O} 13-\mathrm{Tb} 1-\mathrm{O} 1$

$\mathrm{O} 23-\mathrm{Tb} 1-\mathrm{O} 1$

$\mathrm{O} 14-\mathrm{Tb} 1-\mathrm{O} 2$

$\mathrm{O} 12-\mathrm{Tb} 1-\mathrm{O} 2$
0.9900

0.9900

0.77 (2)

$1.4412(15)$

0.9900

0.9900

0.73 (2)

1.537 (2)

1.555 (8)

0.9900

0.9900

0.9900

0.9900

0.9800

0.9800

0.9800

0.9800

72.38 (3)

93.64 (3)

140.67 (3)

83.74 (3)

75.77 (3)

140.58 (3)

138.28 (3)

141.14 (3)

72.06 (3)

83.96 (3)

70.72 (3)

68.99 (3)

71.69 (3)

141.19 (3)

134.33 (3)

69.97 (3)

131.17 (3)

$71.90(3)$

$70.30(3)$

68.34 (3)

123.37 (3)

141.34 (3)

88.98 (3)

79.51 (3)

124.95 (3)

75.88 (3)

71.02 (3)

139.42 (3)

142.17 (3)

73.16 (3)
$\mathrm{C} 25-\mathrm{C} 26$

$\mathrm{C} 25-\mathrm{H} 25 \mathrm{~A}$

$\mathrm{C} 25-\mathrm{H} 25 \mathrm{~B}$

$\mathrm{C} 26-\mathrm{H} 26 \mathrm{~A}$

$\mathrm{C} 26-\mathrm{H} 26 \mathrm{~B}$

$\mathrm{C} 26-\mathrm{H} 26 \mathrm{C}$

$\mathrm{N} 1-\mathrm{O} 3$

$\mathrm{N} 1-\mathrm{O} 1$

$\mathrm{N} 1-\mathrm{O} 2$

$\mathrm{N} 2-\mathrm{O} 4$

N2-O6

$\mathrm{N} 2-\mathrm{O} 5$

N3-O7

N3-O9

$\mathrm{N} 3-\mathrm{O} 8$

$\mathrm{O} 10-\mathrm{H} 1 \mathrm{OA}$

O10- $110 B$

C11-C15-H15D

C17-C15-H15D

H15C-C15-H15D

C15-C16-H16A

C15-C16-H16B

H16A-C16-H16B

C15-C16-H16C

$\mathrm{H} 16 \mathrm{~A}-\mathrm{C} 16-\mathrm{H} 16 \mathrm{C}$

$\mathrm{H} 16 \mathrm{~B}-\mathrm{C} 16-\mathrm{H} 16 \mathrm{C}$

C15-C17-H17A

C15-C17-H17B

H17A-C17-H17B

C15-C17-H17C

H17A-C17-H17C

$\mathrm{H} 17 \mathrm{~B}-\mathrm{C} 17-\mathrm{H} 17 \mathrm{C}$

$\mathrm{C} 22-\mathrm{C} 21-\mathrm{C} 24$

$\mathrm{C} 22-\mathrm{C} 21-\mathrm{C} 23$

$\mathrm{C} 24-\mathrm{C} 21-\mathrm{C} 23$

$\mathrm{C} 22-\mathrm{C} 21-\mathrm{C} 25$

$\mathrm{C} 24-\mathrm{C} 21-\mathrm{C} 25$

$\mathrm{C} 23-\mathrm{C} 21-\mathrm{C} 25$

$\mathrm{O} 22-\mathrm{C} 22-\mathrm{C} 21$

$\mathrm{O} 22-\mathrm{C} 22-\mathrm{H} 22 \mathrm{~A}$

$\mathrm{C} 21-\mathrm{C} 22-\mathrm{H} 22 \mathrm{~A}$

$\mathrm{O} 22-\mathrm{C} 22-\mathrm{H} 22 \mathrm{~B}$

$\mathrm{C} 21-\mathrm{C} 22-\mathrm{H} 22 \mathrm{~B}$

$\mathrm{H} 22 \mathrm{~A}-\mathrm{C} 22-\mathrm{H} 22 \mathrm{~B}$

$\mathrm{C} 22-\mathrm{O} 22-\mathrm{Tb} 1$

$\mathrm{C} 22-\mathrm{O} 22-\mathrm{H} 22 \mathrm{O}$

$\mathrm{Tb} 1-\mathrm{O} 22-\mathrm{H} 22 \mathrm{O}$
$1.526(2)$

0.9900

0.9900

0.9800

0.9800

0.9800

1.2177 (14)

$1.2764(14)$

$1.2775(14)$

$1.2244(15)$

1.2664 (14)

1.2689 (14)

1.2308 (14)

$1.2458(15)$

1.2652 (14)

0.75 (2)

0.79 (2)

108.4

108.4

107.4

109.5

109.5

109.5

109.5

109.5

109.5

109.5

109.5

109.5

109.5

109.5

109.5

111.96 (11)

$110.72(10)$

$110.95(10)$

$108.15(10)$

108.34 (10)

$106.50(10)$

$111.30(10)$

109.4

109.4

109.4

109.4

108.0

130.51 (7)

105.7 (16)

117.7 (16) 


\begin{tabular}{|c|c|c|c|}
\hline $\mathrm{O} 22-\mathrm{Tb} 1-\mathrm{O} 2$ & $123.21(3)$ & $\mathrm{O} 23-\mathrm{C} 23-\mathrm{C} 21$ & $112.77(10)$ \\
\hline $\mathrm{O} 10-\mathrm{Tb} 1-\mathrm{O} 2$ & $73.09(3)$ & $\mathrm{O} 23-\mathrm{C} 23-\mathrm{H} 23 \mathrm{~A}$ & 109.0 \\
\hline $\mathrm{O} 24-\mathrm{Tb} 1-\mathrm{O} 2$ & $69.33(3)$ & $\mathrm{C} 21-\mathrm{C} 23-\mathrm{H} 23 \mathrm{~A}$ & 109.0 \\
\hline $\mathrm{O} 13-\mathrm{Tb} 1-\mathrm{O} 2$ & $110.27(3)$ & $\mathrm{O} 23-\mathrm{C} 23-\mathrm{H} 23 \mathrm{~B}$ & 109.0 \\
\hline $\mathrm{O} 23-\mathrm{Tb} 1-\mathrm{O} 2$ & $125.81(3)$ & $\mathrm{C} 21-\mathrm{C} 23-\mathrm{H} 23 \mathrm{~B}$ & 109.0 \\
\hline $\mathrm{O} 1-\mathrm{Tb} 1-\mathrm{O} 2$ & $51.89(3)$ & $\mathrm{H} 23 \mathrm{~A}-\mathrm{C} 23-\mathrm{H} 23 \mathrm{~B}$ & 107.8 \\
\hline $\mathrm{C} 13-\mathrm{C} 11-\mathrm{C} 12$ & $111.13(11)$ & $\mathrm{C} 23-\mathrm{O} 23-\mathrm{Tb} 1$ & $126.18(7)$ \\
\hline $\mathrm{C} 13-\mathrm{C} 11-\mathrm{C} 14$ & $111.57(10)$ & $\mathrm{C} 23-\mathrm{O} 23-\mathrm{H} 23 \mathrm{O}$ & $107.4(16)$ \\
\hline $\mathrm{C} 12-\mathrm{C} 11-\mathrm{C} 14$ & $111.21(10)$ & $\mathrm{Tb} 1-\mathrm{O} 23-\mathrm{H} 23 \mathrm{O}$ & $109.0(16)$ \\
\hline $\mathrm{C} 13-\mathrm{C} 11-\mathrm{C} 15$ & $108.69(10)$ & $\mathrm{O} 24-\mathrm{C} 24-\mathrm{C} 21$ & $111.24(10)$ \\
\hline $\mathrm{C} 12-\mathrm{C} 11-\mathrm{C} 15$ & $106.67(10)$ & $\mathrm{O} 24-\mathrm{C} 24-\mathrm{H} 24 \mathrm{~A}$ & 109.4 \\
\hline $\mathrm{C} 14-\mathrm{C} 11-\mathrm{C} 15$ & $107.34(10)$ & $\mathrm{C} 21-\mathrm{C} 24-\mathrm{H} 24 \mathrm{~A}$ & 109.4 \\
\hline $\mathrm{O} 12-\mathrm{C} 12-\mathrm{C} 11$ & $111.87(10)$ & $\mathrm{O} 24-\mathrm{C} 24-\mathrm{H} 24 \mathrm{~B}$ & 109.4 \\
\hline $\mathrm{O} 12-\mathrm{C} 12-\mathrm{H} 12 \mathrm{~A}$ & 109.2 & $\mathrm{C} 21-\mathrm{C} 24-\mathrm{H} 24 \mathrm{~B}$ & 109.4 \\
\hline $\mathrm{C} 11-\mathrm{C} 12-\mathrm{H} 12 \mathrm{~A}$ & 109.2 & $\mathrm{H} 24 \mathrm{~A}-\mathrm{C} 24-\mathrm{H} 24 \mathrm{~B}$ & 108.0 \\
\hline $\mathrm{O} 12-\mathrm{C} 12-\mathrm{H} 12 \mathrm{~B}$ & 109.2 & $\mathrm{C} 24-\mathrm{O} 24-\mathrm{Tb} 1$ & $131.10(8)$ \\
\hline $\mathrm{C} 11-\mathrm{C} 12-\mathrm{H} 12 \mathrm{~B}$ & 109.2 & $\mathrm{C} 24-\mathrm{O} 24-\mathrm{H} 24 \mathrm{O}$ & $108.4(15)$ \\
\hline $\mathrm{H} 12 \mathrm{~A}-\mathrm{C} 12-\mathrm{H} 12 \mathrm{~B}$ & 107.9 & $\mathrm{~Tb} 1-\mathrm{O} 24-\mathrm{H} 24 \mathrm{O}$ & $118.9(15)$ \\
\hline $\mathrm{C} 12-\mathrm{O} 12-\mathrm{Tb} 1$ & $132.24(8)$ & $\mathrm{C} 26-\mathrm{C} 25-\mathrm{C} 21$ & $115.88(12)$ \\
\hline $\mathrm{C} 12-\mathrm{O} 12-\mathrm{H} 12 \mathrm{O}$ & $109.7(15)$ & $\mathrm{C} 26-\mathrm{C} 25-\mathrm{H} 25 \mathrm{~A}$ & 108.3 \\
\hline $\mathrm{Tb} 1-\mathrm{O} 12-\mathrm{H} 12 \mathrm{O}$ & $117.7(15)$ & $\mathrm{C} 21-\mathrm{C} 25-\mathrm{H} 25 \mathrm{~A}$ & 108.3 \\
\hline $\mathrm{O} 13-\mathrm{C} 13-\mathrm{C} 11$ & $111.25(10)$ & $\mathrm{C} 26-\mathrm{C} 25-\mathrm{H} 25 \mathrm{~B}$ & 108.3 \\
\hline $\mathrm{O} 13-\mathrm{C} 13-\mathrm{H} 13 \mathrm{~A}$ & 109.4 & $\mathrm{C} 21-\mathrm{C} 25-\mathrm{H} 25 \mathrm{~B}$ & 108.3 \\
\hline $\mathrm{C} 11-\mathrm{C} 13-\mathrm{H} 13 \mathrm{~A}$ & 109.4 & $\mathrm{H} 25 \mathrm{~A}-\mathrm{C} 25-\mathrm{H} 25 \mathrm{~B}$ & 107.4 \\
\hline $\mathrm{O} 13-\mathrm{C} 13-\mathrm{H} 13 \mathrm{~B}$ & 109.4 & $\mathrm{C} 25-\mathrm{C} 26-\mathrm{H} 26 \mathrm{~A}$ & 109.5 \\
\hline $\mathrm{C} 11-\mathrm{C} 13-\mathrm{H} 13 \mathrm{~B}$ & 109.4 & $\mathrm{C} 25-\mathrm{C} 26-\mathrm{H} 26 \mathrm{~B}$ & 109.5 \\
\hline $\mathrm{H} 13 \mathrm{~A}-\mathrm{C} 13-\mathrm{H} 13 \mathrm{~B}$ & 108.0 & $\mathrm{H} 26 \mathrm{~A}-\mathrm{C} 26-\mathrm{H} 26 \mathrm{~B}$ & 109.5 \\
\hline $\mathrm{C} 13-\mathrm{O} 13-\mathrm{Tb} 1$ & $129.81(7)$ & $\mathrm{C} 25-\mathrm{C} 26-\mathrm{H} 26 \mathrm{C}$ & 109.5 \\
\hline $\mathrm{C} 13-\mathrm{O} 13-\mathrm{H} 13 \mathrm{O}$ & $107.0(15)$ & $\mathrm{H} 26 \mathrm{~A}-\mathrm{C} 26-\mathrm{H} 26 \mathrm{C}$ & 109.5 \\
\hline $\mathrm{Tb} 1-\mathrm{O} 13-\mathrm{H} 13 \mathrm{O}$ & $121.7(15)$ & $\mathrm{H} 26 \mathrm{~B}-\mathrm{C} 26-\mathrm{H} 26 \mathrm{C}$ & 109.5 \\
\hline $\mathrm{O} 14-\mathrm{C} 14-\mathrm{C} 11$ & $111.38(10)$ & $\mathrm{O} 3-\mathrm{N} 1-\mathrm{O} 1$ & $122.06(11)$ \\
\hline $\mathrm{O} 14-\mathrm{C} 14-\mathrm{H} 14 \mathrm{~A}$ & 109.4 & $\mathrm{O} 3-\mathrm{N} 1-\mathrm{O} 2$ & $122.07(11)$ \\
\hline $\mathrm{C} 11-\mathrm{C} 14-\mathrm{H} 14 \mathrm{~A}$ & 109.4 & $\mathrm{O} 1-\mathrm{N} 1-\mathrm{O} 2$ & $115.87(10)$ \\
\hline $\mathrm{O} 14-\mathrm{C} 14-\mathrm{H} 14 \mathrm{~B}$ & 109.4 & $\mathrm{O} 3-\mathrm{N} 1-\mathrm{Tb} 1$ & $177.09(9)$ \\
\hline $\mathrm{C} 11-\mathrm{C} 14-\mathrm{H} 14 \mathrm{~B}$ & 109.4 & $\mathrm{O} 1-\mathrm{N} 1-\mathrm{Tb} 1$ & $57.85(6)$ \\
\hline $\mathrm{H} 14 \mathrm{~A}-\mathrm{C} 14-\mathrm{H} 14 \mathrm{~B}$ & 108.0 & $\mathrm{O} 2-\mathrm{N} 1-\mathrm{Tb} 1$ & $58.10(6)$ \\
\hline $\mathrm{C} 14-\mathrm{O} 14-\mathrm{Tb} 1$ & $131.09(8)$ & $\mathrm{N} 1-\mathrm{O} 1-\mathrm{Tb} 1$ & $96.21(7)$ \\
\hline $\mathrm{C} 14-\mathrm{O} 14-\mathrm{H} 14 \mathrm{O}$ & $108.8(16)$ & $\mathrm{N} 1-\mathrm{O} 2-\mathrm{Tb} 1$ & $95.92(7)$ \\
\hline $\mathrm{Tb} 1-\mathrm{O} 14-\mathrm{H} 14 \mathrm{O}$ & $119.6(16)$ & $\mathrm{O} 4-\mathrm{N} 2-\mathrm{O} 6$ & $121.06(11)$ \\
\hline $\mathrm{C} 16-\mathrm{C} 15-\mathrm{C} 11$ & $116.37(12)$ & $\mathrm{O} 4-\mathrm{N} 2-\mathrm{O} 5$ & $120.92(11)$ \\
\hline $\mathrm{C} 11-\mathrm{C} 15-\mathrm{C} 17$ & $115.6(3)$ & $\mathrm{O} 6-\mathrm{N} 2-\mathrm{O} 5$ & $118.02(10)$ \\
\hline $\mathrm{C} 16-\mathrm{C} 15-\mathrm{H} 15 \mathrm{~A}$ & 108.2 & $\mathrm{O} 7-\mathrm{N} 3-\mathrm{O} 9$ & $120.49(11)$ \\
\hline $\mathrm{C} 11-\mathrm{C} 15-\mathrm{H} 15 \mathrm{~A}$ & 108.2 & $\mathrm{O} 7-\mathrm{N} 3-\mathrm{O} 8$ & $120.47(11)$ \\
\hline $\mathrm{C} 16-\mathrm{C} 15-\mathrm{H} 15 \mathrm{~B}$ & 108.2 & $\mathrm{O} 9-\mathrm{N} 3-\mathrm{O} 8$ & $119.01(11)$ \\
\hline $\mathrm{C} 11-\mathrm{C} 15-\mathrm{H} 15 \mathrm{~B}$ & 108.2 & $\mathrm{~Tb} 1-\mathrm{O} 10-\mathrm{H} 1 \mathrm{OA}$ & $124.7(16)$ \\
\hline $\mathrm{H} 15 \mathrm{~A}-\mathrm{C} 15-\mathrm{H} 15 \mathrm{~B}$ & 107.3 & $\mathrm{~Tb} 1-\mathrm{O} 10-\mathrm{H} 1 \mathrm{OB}$ & $122.4(15)$ \\
\hline $\mathrm{C} 11-\mathrm{C} 15-\mathrm{H} 15 \mathrm{C}$ & 108.4 & $\mathrm{H} 1 \mathrm{OA}-\mathrm{O} 10-\mathrm{H} 1 \mathrm{OB}$ & $113(2)$ \\
\hline $\mathrm{C} 17-\mathrm{C} 15-\mathrm{H} 15 \mathrm{C}$ & 108.4 & & \\
\hline
\end{tabular}




$\begin{array}{llll}\mathrm{C} 13-\mathrm{C} 11-\mathrm{C} 12-\mathrm{O} 12 & -72.04(13) & \mathrm{C} 23-\mathrm{C} 21-\mathrm{C} 22-\mathrm{O} 22 & 46.85(14) \\ \mathrm{C} 14-\mathrm{C} 11-\mathrm{C} 12-\mathrm{O} 12 & 52.90(14) & \mathrm{C} 25-\mathrm{C} 21-\mathrm{C} 22-\mathrm{O} 22 & 163.18(10) \\ \mathrm{C} 15-\mathrm{C} 11-\mathrm{C} 12-\mathrm{O} 12 & 169.64(10) & \mathrm{C} 21-\mathrm{C} 22-\mathrm{O} 22-\mathrm{Tb} 1 & 29.13(15) \\ \mathrm{C} 11-\mathrm{C} 12-\mathrm{O} 12-\mathrm{T} 1 & 17.38(16) & \mathrm{C} 22-\mathrm{C} 21-\mathrm{C} 23-\mathrm{O} 23 & -79.94(13) \\ \mathrm{C} 12-\mathrm{C} 11-\mathrm{C} 13-\mathrm{O} 13 & 49.60(14) & \mathrm{C} 24-\mathrm{C} 21-\mathrm{C} 23-\mathrm{O} 23 & 45.02(14) \\ \mathrm{C} 14-\mathrm{C} 11-\mathrm{C} 13-\mathrm{O} 13 & -75.14(13) & \mathrm{C} 25-\mathrm{C} 21-\mathrm{C} 23-\mathrm{O} 23 & 162.72(10) \\ \mathrm{C} 15-\mathrm{C} 11-\mathrm{C} 13-\mathrm{O} 13 & 166.69(11) & \mathrm{C} 21-\mathrm{C} 23-\mathrm{O} 23-\mathrm{Tb} 1 & 33.74(14) \\ \mathrm{C} 11-\mathrm{C} 13-\mathrm{O} 13-\mathrm{T} 1 & 25.43(15) & \mathrm{C} 22-\mathrm{C} 21-\mathrm{C} 24-\mathrm{O} 24 & 51.36(14) \\ \mathrm{C} 13-\mathrm{C} 11-\mathrm{C} 14-\mathrm{O} 14 & 49.60(14) & \mathrm{C} 23-\mathrm{C} 21-\mathrm{C} 24-\mathrm{O} 24 & -72.89(13) \\ \mathrm{C} 12-\mathrm{C} 11-\mathrm{C} 14-\mathrm{O} 14 & -75.10(13) & \mathrm{C} 25-\mathrm{C} 21-\mathrm{C} 24-\mathrm{O} 24 & 170.54(10) \\ \mathrm{C} 15-\mathrm{C} 11-\mathrm{C} 14-\mathrm{O} 14 & 168.57(10) & \mathrm{C} 21-\mathrm{C} 24-\mathrm{O} 24-\mathrm{Tb} 1 & 20.64(15) \\ \mathrm{C} 11-\mathrm{C} 14-\mathrm{O} 14-\mathrm{Tb} 1 & 26.41(15) & \mathrm{C} 22-\mathrm{C} 21-\mathrm{C} 25-\mathrm{C} 26 & 44.73(15) \\ \mathrm{C} 13-\mathrm{C} 11-\mathrm{C} 15-\mathrm{C} 16 & 49.30(16) & \mathrm{C} 24-\mathrm{C} 21-\mathrm{C} 25-\mathrm{C} 26 & -76.83(14) \\ \mathrm{C} 12-\mathrm{C} 11-\mathrm{C} 15-\mathrm{C} 16 & 169.20(12) & \mathrm{C} 23-\mathrm{C} 21-\mathrm{C} 25-\mathrm{C} 26 & 163.76(11) \\ \mathrm{C} 14-\mathrm{C} 11-\mathrm{C} 15-\mathrm{C} 16 & -71.51(15) & \mathrm{O} 3-\mathrm{N} 1-\mathrm{O} 1-\mathrm{Tb} 1 & 176.57(10) \\ \mathrm{C} 13-\mathrm{C} 11-\mathrm{C} 15-\mathrm{C} 17 & -70.7(3) & \mathrm{O} 2-\mathrm{N} 1-\mathrm{O} 1-\mathrm{Tb} 1 & -3.17(11) \\ \mathrm{C} 12-\mathrm{C} 11-\mathrm{C} 15-\mathrm{C} 17 & 49.2(3) & \mathrm{O} 3-\mathrm{N} 1-\mathrm{O} 2-\mathrm{Tb} 1 & -176.58(10) \\ \mathrm{C} 14-\mathrm{C} 11-\mathrm{C} 15-\mathrm{C} 17 & 168.5(3) & \mathrm{O} 1-\mathrm{N} 1-\mathrm{O} 2-\mathrm{Tb} 1 & 3.16(11) \\ \mathrm{C} 24-\mathrm{C} 21-\mathrm{C} 22-\mathrm{O} 22 & -77.54(13) & & \end{array}$

Hydrogen-bond geometry $\left(\AA,{ }^{\circ}\right)$

\begin{tabular}{|c|c|c|c|c|}
\hline$D-\mathrm{H} \cdots A$ & $D-\mathrm{H}$ & $\mathrm{H} \cdots A$ & $D \cdots A$ & $D-\mathrm{H} \cdots A$ \\
\hline $\mathrm{O} 10-\mathrm{H} 1 O A \cdots \mathrm{O}^{\mathrm{i}}$ & $0.75(2)$ & $2.03(2)$ & $2.7420(14)$ & $159(2)$ \\
\hline $\mathrm{O} 10-\mathrm{H} 1 O B \cdots \mathrm{O} 5^{\mathrm{ii}}$ & $0.79(2)$ & $2.00(2)$ & $2.7703(14)$ & $167(2)$ \\
\hline $\mathrm{O} 13-\mathrm{H} 13 O \cdots \mathrm{O} 8$ & $0.77(2)$ & $1.91(2)$ & $2.6695(14)$ & $169(2)$ \\
\hline $\mathrm{O} 12-\mathrm{H} 12 O \cdots \mathrm{O} 5^{\mathrm{iii}}$ & $0.74(2)$ & $1.93(2)$ & $2.6713(13)$ & $174(2)$ \\
\hline $\mathrm{O} 14-\mathrm{H} 140 \cdots \mathrm{O} 6$ & $0.73(2)$ & $1.97(2)$ & $2.6992(14)$ & $174(2)$ \\
\hline $\mathrm{O} 23-\mathrm{H} 23 O \cdots \mathrm{O} 6^{\mathrm{ii}}$ & $0.71(2)$ & $2.09(2)$ & $2.7669(14)$ & $161(2)$ \\
\hline $\mathrm{O} 22-\mathrm{H} 22 \mathrm{O} \cdots \mathrm{O} 9$ & $0.76(2)$ & $1.94(2)$ & $2.6609(14)$ & $157(2)$ \\
\hline $\mathrm{O} 24-\mathrm{H} 24 O \cdots \mathrm{O} 8^{\text {iv }}$ & $0.73(2)$ & $1.97(2)$ & $2.6650(14)$ & $158(2)$ \\
\hline $\mathrm{C} 14-\mathrm{H} 14 A^{\cdots} \mathrm{O}^{\mathrm{i}}$ & 0.99 & 2.58 & $3.3462(17)$ & 135 \\
\hline $\mathrm{C} 23-\mathrm{H} 23 A \cdots 3^{v}$ & 0.99 & 2.51 & $3.4003(16)$ & 149 \\
\hline
\end{tabular}

Symmetry codes: (i) $x,-y+1 / 2, z+1 / 2$; (ii) $-x+1,-y+1,-z+1$; (iii) $x-1, y, z$; (iv) $-x, y+1 / 2,-z+1 / 2$; (v) $x+1, y, z$. 